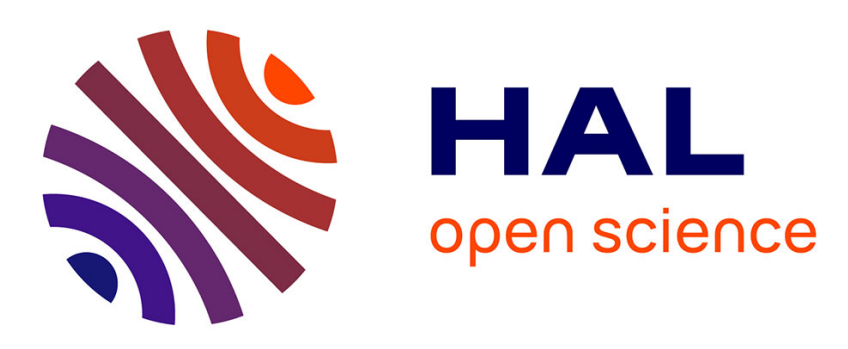

\title{
Sesuvium portulacastrum, a plant for drought, salt stress, sand fixation, food and phytoremediation. A review
}

Vinayak Lokhande, Bhoomi Gor, Neetin Desai, Tukaram Nikam, Penna Suprasanna

\section{To cite this version:}

Vinayak Lokhande, Bhoomi Gor, Neetin Desai, Tukaram Nikam, Penna Suprasanna. Sesuvium portulacastrum, a plant for drought, salt stress, sand fixation, food and phytoremediation. A review. Agronomy for Sustainable Development, 2013, 33 (2), pp.329-348. 10.1007/s13593-012-0113-x . hal01201356

\section{HAL Id: hal-01201356 \\ https://hal.science/hal-01201356}

Submitted on 17 Sep 2015

HAL is a multi-disciplinary open access archive for the deposit and dissemination of scientific research documents, whether they are published or not. The documents may come from teaching and research institutions in France or abroad, or from public or private research centers.
L'archive ouverte pluridisciplinaire HAL, est destinée au dépôt et à la diffusion de documents scientifiques de niveau recherche, publiés ou non, émanant des établissements d'enseignement et de recherche français ou étrangers, des laboratoires publics ou privés. 


\title{
Sesuvium portulacastrum, a plant for drought, salt stress, sand fixation, food and phytoremediation. A review
}

\author{
Vinayak H. Lokhande • Bhoomi K. Gor • \\ Neetin S. Desai • Tukaram D. Nikam • \\ Penna Suprasanna
}

Accepted: 28 August 2012 / Published online: 3 October 2012

(C) INRA and Springer-Verlag, France 2012

\begin{abstract}
Sesuvium portulacastrum L. is a pioneer plant species, used for sand-dune fixation, desalination and phytoremediation along coastal regions. The plant tolerates abiotic constraints such as salinity, drought and toxic metals. S. portulacastrum is also used as a vegetable, fodder for domestic animals and as an ornamental plant. S. portulacastrum grows luxuriantly at $100-400 \mathrm{mM} \mathrm{NaCl}$ concentrations. It further grows at severe salinity of $1000 \mathrm{mM} \mathrm{NaCl}$ without any toxic symptoms on the leaves. The plant also produces 20-hydroxyecdysone, an insect molting hormone for use in sericulture industry. This review analyses research undertaken during last two to three decades in physiology, biochemistry, molecular biology and biotechnology, to unravel the plasticity of the plant tolerance mechanism. Physiological and biochemical studies evidence the tolerance potential of the plant to
\end{abstract}

Vinayak H. Lokhande and Bhoomi K. Gor have contributed equally to this work.

V. H. Lokhande • T. D. Nikam

Shri Shiv Chhatrapati College of Arts, Commerce and Science, Bodkenagar, Junnar,

Tal. Junnar, Dist. Pune 410 502, India

B. K. Gor $\cdot$ N. S. Desai

Department of Biotechnology and Bioinformatics,

Padmashree Dr. D. Y. Patil University,

C. B. D. Belapur,

Navi Mumbai 400614, India

P. Suprasanna $(\square)$

Functional Plant Biology Section, Nuclear Agriculture and

Biotechnology Division, Bhabha Atomic Research Centre,

Trombay, Mumbai 400 085, India

e-mail: penna888@yahoo.com

T. D. Nikam

Department of Botany, University of Pune,

Pune 411007, India abiotic stresses and reveal molecular mechanisms of stress tolerance. Biotechnological studies show the efficacy of the plant to produce pharmaceuticals. Large-scale multiplication of $S$. portulacastrum in the arid and semiarid regions should reduce the load of saline salts and heavy metals.

Keywords Sesuvium portulacastrum L. · Abiotic stress tolerance Environmental protection $\cdot$ Halophyte .

20-Hydroxyecdysone $\cdot$ Desalination $\cdot$ Phytoremediation

$\begin{array}{ll}\text { Abbreviations } \\ \text { 20E } & \text { 20-Hydroxyecdysone } \\ \text { ADP } & \text { Adenosine 5'-diphosphate } \\ \text { APX } & \text { Ascorbate peroxidase } \\ \text { ASC } & \text { Ascorbate } \\ \text { ATP } & \text { Adenosine } 5^{\prime} \text {-triphosphate } \\ \text { CAT } & \text { Catalase } \\ \text { DHA } & \text { Dehydroascorbate } \\ \text { dS } & \text { DesiSiemens } \\ \text { FBA } & \text { Fructose-1,6-bisphosphate aldolase } \\ \text { GSH } & \text { Glutathione (reduced) } \\ \text { GSSG } & \text { Glutathione (oxidised) } \\ \text { KUE } & \text { Potassium use efficiency } \\ \text { MPa } & \text { MegaPascal } \\ \text { MS } & \text { Murashige and Skoog basal medium } \\ \text { NADH } & \text { Nicotinamide adenine dinucleotide reduced } \\ \text { NADME } & \text { NAD-mallic enzyme } \\ \text { NADP } & \text { Nicotinamide adenine dinucleotide phosphate } \\ \text { NADPH } & \text { Nicotinamide adenine dinucleotide phosphate } \\ & \text { Reduced } \\ \text { PC3 } & \text { Phytochelatin 3 } \\ \text { PS } & \text { Photosystem } \\ \text { ROS } & \text { Reactive oxygen species } \\ \text { SOD } & \text { Superoxide dismutase } \\ \text { SQDG } & \text { Sulphoquinovosyldiacylglycerol } \\ \text { SSH } & \text { Suppressive subtractive hybridisation }\end{array}$




\section{Contents}

1. Introduction. . . . . . . . . . . . . . . . 2

2. Morphology, habitat, and distribution. . . . . . . 3

3. Stress tolerance . . . . . . . . . . . . . . . 3

3.1 Growth and halosucculence ........... 3

3.2 Photosynthesis . . . . . . . . . . . . . . .4

3.3 Ion transport and osmolytes accumulation ..... . 5

3.4 Tolerance to oxidative stress . . . . . . . . . . 9

3.5 Redox homeostasis and energetic status . . . . . . .9 9

3.6 Other mechanisms of stress tolerance . . . . . . .9 9

3.7 Tolerance to heavy metals . . . . . . . . . 11

4. Molecular studies . . . . . . . . . . . . . . . . 13

5. Biotechnological implications . . . . . . . . 13

6. Metabolites . . . . . . . . . . . . . . . . . . . 14

7. Potential applications of Sesuvium portulacastrum .15

7.1 Medicinal uses . . . . . . . . . . . . . 15

7.2 Source of nutritious food and fodder. . . . . . 15

7.3 Source of organic fertiliser and preservative . . 15

8. Pioneer role in environment protection . . . . . . . . . . . . . . . . .

9. Summary and conclusions. . . . . . . . . . . 16

\section{Introduction}

Salinity is one of the major abiotic constraints, manifesting as osmotic stress at an early and ionic stress at later phases of plant growth, consequently affecting plants' survival mechanisms at cellular, tissue and whole plant level (Hasegawa et al. 2000; Munns and Tester 2008). These osmotic and ionic stresses affect the entire biology of a plant including growth, morphological, anatomical, physiological, biochemical and molecular features. It has been estimated that more than 800 million hectares of land considering $20 \%$ of all cultivated and nearly half of irrigated land throughout the world is affected by salt (FAO 2008) and this accounts for more than $6 \%$ of the world's total land area (Munns and Tester 2008). Experimentally, soils are classified as saline when the electrical conductivity of the saturated paste extract is $4 \mathrm{dS} \mathrm{m}^{-1}$ or more, which is equivalent to $40 \mathrm{mM} \mathrm{NaCl}$ and generate an osmotic pressure of approximately 0.2 $\mathrm{MPa}$. Plants differ greatly in their growth response to saline conditions and are traditionally classified as glycophytes or halophytes rendering to grow on saline environments (Munns and Tester 2008). $\mathrm{NaCl}$ rich soil, which actually inhibits survival of nearly $99 \%$ of plant species (glycophytes), is an optimal soil condition for halophytes to survive and complete their life cycle (Flowers and Colmer 2008). These halophytic plant species are morphologically, anatomically and physiologically well adapted to thrive and flourish in soils with high salt concentrations (Flowers et al. 1977; Flowers and Colmer 2008, Lokhande and Suprasanna 2012). The use of saline ions as an inorganic osmoticum is an economical trait attributed to these naturally salt-tolerant species (Subbarao et al. 2001a). It has been theorised that salt tolerance effectors and regulatory pathways in both halophytes and glycophytes are alike but subtle variations in the regulation of these pathways have contributed to their survival in saline soils (Zhu 2001). Some halophytes consistently require a particular concentration of salt in the growth medium, (called as 'obligate halophytes' or 'true mangroves') whereas, apart from their growth in highly saline environment, some halophytes have capacity to grow on the soil devoid of salt or soil with mild levels of $\mathrm{NaCl}$ (called as 'facultative halophytes' or 'mangrove associates'). This presence or absence of substrate in the form of salt offers benefit for facultative halophytes in the competition with salt-sensitive plants (glycophytes).

Among the different halophytic species (Mesembryanthemum crystallinum, Suaeda salsa, Thellungiella halophila, Atriplex sps. etc.), Sesuvium portulacastrum L., commonly called "Sea purslane", is an important halophyte of the family Aizoaceae. This plant has a distinct molecular and physiological flexibility that enables it to adapt and survive under various abiotic stress conditions (Venkatesalu et al. 1994a, b; Messedi et al. 2004; Ghnaya et al. 2005, 2007a,b; Ramani et al. 2004a, b, c, 2006; Slama et al. 2006, 2007a, b, 2008; Rabhi et al. 2010a, b; Lokhande et al. 2009a, b, 2010a, b, c, Lokhande et al. 2011a, b, c; Moseki and Buru 2010; Zaier et al. 2010a, b). In the past two decades, considerable research progress has been made to highlight its importance and application in desalinisation, phytoremediation and environmental protection. In this article, we have presented an overview of the biology of Sesuvium, mechanisms of halophytic behaviour, different metabolic cues for stress management and the plants' potential for environmental conservation and sustainable agriculture.

\section{Morphology, habitat and distribution}

S. portulacastrum (Fig. 1a) is a herbaceous, perennial, psammophytic, dicotyledonous and facultative halophyte belonging to family Aizoaceae (Lonard and Judd 1997; Lokhande et al. 2009a) with somatic chromosome number $2 n=48$ (Jena et al. 2003). The plant has various synonyms as well as common names according to its distribution among different parts of the world (Lonard and Judd 1997; Hammer 2001; Lokhande et al. 2009a). Plant possess tap root system, however, creeping nature produces adventitious roots from the nodal region. Shoots are trailing or sub-teret glabrous herb erect, succulent and greenish pink or red in colour and are diffusely branched with oppositely arranged simple, succulent leaves containing paracyctic stomata (Joshi and Bhosale 1981). The plant produces commonly pink to purple and very rarely white flowers and bloom throughout the year (Fig. 1b, c). It produces circumscissile fruits (capsule) enclosing small stalked black, smooth and lustrous seeds (Fig. 1d) and each fruit produced 50 or more 
Fig. 1 Morphology of $S$. portulacastrum showing plants with pink- and white-coloured flowers and seeds (Lokhande et al. 2009a, b)

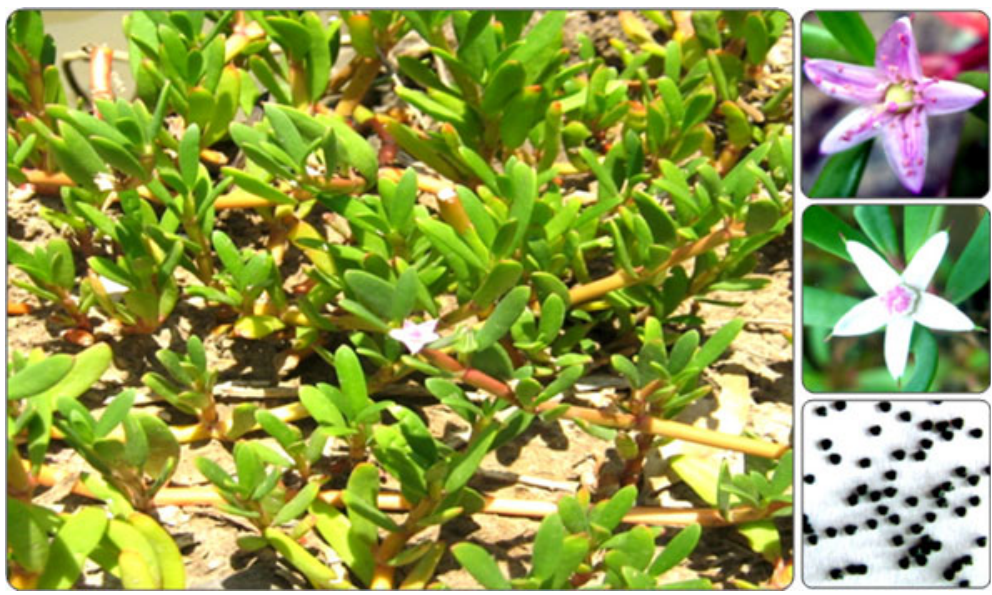

seeds per capsule (Lonard and Judd 1997; Lokhande et al. 2009a). Variation in temperature, light fluctuation and salinity (Martinez et al. 1992) causes poor seed germination, hence vegetative method through stem cutting is a preferred mode of propagation.

Sesuvium usually grows in wet sandy locations such as beaches, mangroves, dunes, salt flats and marshes. It is seen to inhabit areas with annual rainfall as little as 50 to $150 \mathrm{~cm}$ and can remain green in areas with long dry seasons and in habitats subjected to salt spray. S. portulacastrum grows on the coastlines of five continents and is widely distributed as a pioneer strand species on tropical and sub-tropical shores extended from the equator about $34^{\circ}$ north latitude and $42^{\circ}$ south latitude (Lonard and Judd 1997). It grows naturally in the sub-tropical, Mediterranean, coastal and warmer areas around the world (Ramani et al. 2006).

\section{Stress tolerance}

\subsection{Growth and halosucculence}

Under abiotic stresses (salt, drought and heavy metal), Sesuvium exhibits various adaptations through morphological and anatomical growth, water use efficiency, physiological and biochemical changes. The growth observed in terms of length, fresh and dry weight of root and shoots, root/shoot ratio, number of leaves and leaf area is found to significantly decrease under higher salt, drought and heavy metal exposure, alone or in combinations (Venkatesalu and Chellapan 1993a, b; Venkatesalu et al. 1994a, b; Messedi et al. 2004; Ghnaya et al. 2005, 2007a, b; Ramani et al. 2004a, b, c; Nouairi et al. 2006; Slama et al. 2006, 2007a, b; Slama et al. 2008; Lokhande et al. 2010a, b, c; Lokhande et al. 2011a, b; Moseki and Buru 2010). However, improved growth of Sesuvium under lower concentrations of salt alone or in combination with drought and favourable concentrations of heavy metal has been correlated with increased succulence, modulated water potential, optimum levels of mineral ion accumulation along with the physiological and biochemical (osmotic adjustment through osmolytes synthesis, activities of enzymatic and non-enzymatic antioxidants) changes. Furthermore, it has been observed that upon removal of long-term or short-term stress, substantial recovery is observed in most of the parameters related to growth, development, hydric status and nutrition (Slama et al. 2006, 2007a, b, 2008). Thus Sesuvium may be conserving growth potential and nutrition acquisition during stress period as an outcome of decreased water potential and increased water-use efficiency (Slama et al. 2006).

The succulent halophytes unlike glycophytes tend to accumulate $\mathrm{Na}^{+}$in the vacuoles to higher levels than in the cytoplasm (Yeo and Flowers 1986). S. portulacastrum, being a facultative halophyte and 'salt accumulator', grows well under severe salinity $(100-400 \mathrm{mM} \mathrm{NaCl})$ and low nutrient availability. The emerging data on adaptability of the plant exposed to various abiotic factors reveal that $S$. portulacastrum maintains its growth by sequestration of saline ions and heavy metals into the vacuoles to maintain the osmotic balance between vacuole and cytoplasm (Venkatesalu and Chellapan 1993a, b; Messedi et al. 2004; Ghnaya et al. 2005, 2007a,b; Ramani et al. 2004a, b, c, 2006; Slama et al. 2007a, b, 2008; Lokhande et al. 2010a, b, c, 2011a, b; Moseki and Buru 2010).

Within a range of salt concentrations optimal for growth, the sequestration of saline ions into the vacuoles results in increased succulence of the plant's vegetative parts which is a common characteristic of the halophytes (commonly called as halosucculence) (Short and Colmer 1999). Succulence minimises the toxic effect of excessive ion accumulation and is associated with accretion of osmotically active solutes for maintenance of cell turgor pressure (Luttge and Smith 1984). It has been observed that the growth characteristics of Sesuvium were improved upon exposure to optimum $\mathrm{NaCl}$ concentrations (100 to $400 \mathrm{mM}$ ) under in vitro and an increase in growth rate and halosucculence status (200 $\mathrm{mM}$ of $\mathrm{NaCl}$ ) under ex vitro conditions (Lokhande et 
al. 2010a, b, 2011a; Rabhi et al. 2010a, b; Moseki and Buru 2010) (Figs. 2 and 3). Sesuvium can optimally uptake saline ions and carbon resources from the medium and allocate it to different parts of the plant resulting in increase succulence subsequently improving the growth, biomass and net photosynthesis rate of the plant (Venkatesalu and Chellapan 1993a, b; Messedi et al. 2004; Ghnaya et al. 2005, Ghnaya et al. 2007a,b; Slama et al. 2006, 2007a, b, 2008; Rabhi et al. 2010a, b; Moseki and Buru 2010). Net $\mathrm{CO}_{2}$ assimilation rate increased under salinity up to 3 weeks of treatment (200 and $400 \mathrm{mM} \mathrm{NaCl}$ ) then decreased to reach the value of 0 $\mathrm{mM}$-treated plants whereas stomatal conductance and intercellular $\mathrm{CO}_{2}$ concentration displayed the opposite trend (Rabhi et al. 2010a,b). Rationale for succulence characteristic of Sesuvium is (1) increased succulence having a 'diluting' effect on the ion content of cells which might otherwise rise to toxic levels, and (2) as $\mathrm{Na}^{+}$ions acts as a specific stimulant of growth - it may be contributing to reduce turgor pressure component of the water potential of the cell (Jennings 1968). The property of halosucculence may aid Sesuvium to adapt to various environmental stresses. It can be postulated that the absorbed $\mathrm{Na}^{+}$ions may be acting as signaling molecules to initiate signal transduction cascade for salt-adaptation mechanism as observed in the halophyte $M$. crystallinum exposed to $200 \mathrm{mM} \mathrm{NaCl}$ (Yang and Yen 2002), however, this postulation requires validation in case of Sesuvium. In a recent study, Wang et al. (2012) demonstrated that salt-treated plants accumulated large amounts of $\mathrm{Na}^{+}$in both leaf and stem, and there was a greater shoot growth in presence of external $\mathrm{Na}^{+}$compared to $\mathrm{K}^{+}$and $\mathrm{Cl}^{-}$. $\mathrm{Na}^{+}$was found more effective than $\mathrm{K}^{+}$ and $\mathrm{Cl}^{-}$in cell expansion, leaf succulence and shoot development plants supplied with $200 \mathrm{mM}$. A generalised mechanistic viewpoint on the salinity stress responses in the plant and biochemical attributes of $S$. portulacastrum exposed to 250 and 1,000 $\mathrm{mM} \mathrm{NaCl}$ stress is presented in Fig. 4.

\subsection{Photosynthesis}

Plants need to economise photosynthetic efficiency to cope with abiotic stresses. Reduced stomatal conductance and
Fig. 2 Effect of different salt concentrations on the growth of Sesuvium shoots in vitro. The axillary shoots were transferred to media containing $0-600 \mathrm{mM}$ $\mathrm{NaCl}$, and the number of shoots and leaves per explant, and the shoot and leaf length was measured after 30 days of culture. The error bars indicate the standard error (SE; $n=21)$. The values are significantly different at $P \leq 0.05$, according to a least significant difference test (Lokhande et al. 2011a)
No. of shoots and leaves per explant ${ }^{-1}$

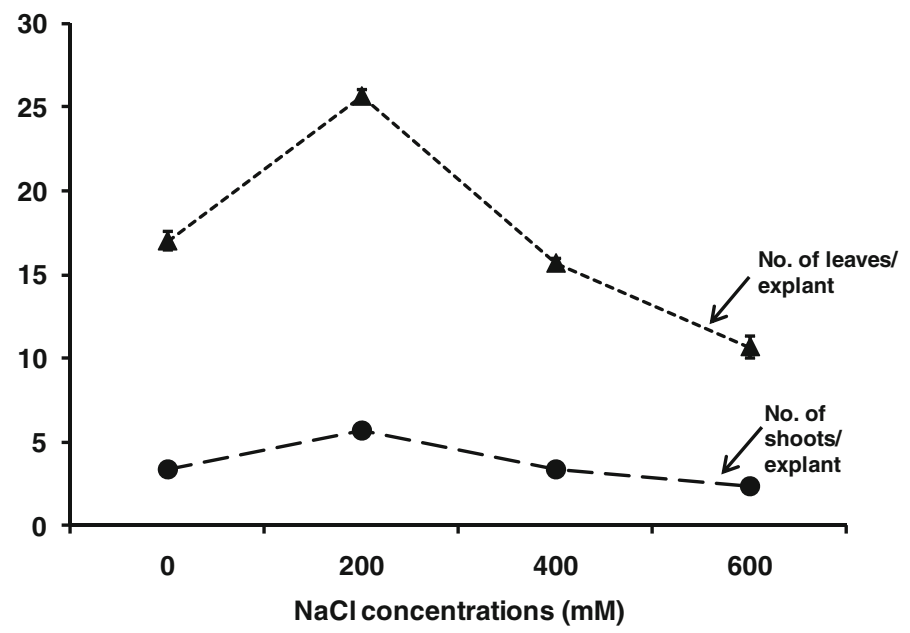

Shoot and leaf length $(\mathrm{mm})$

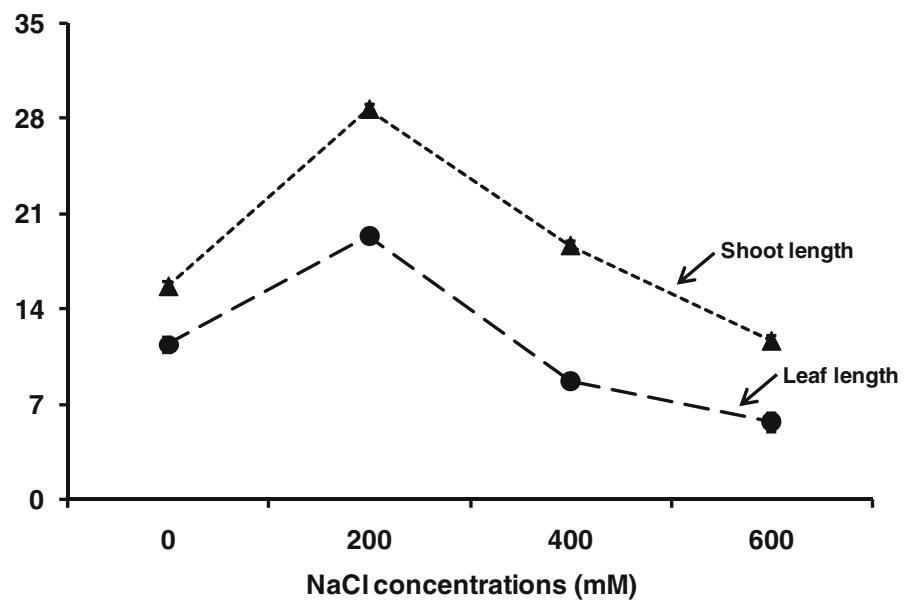


Fig. 3 Halosucculence status of Sesuvium shoots under different salt concentrations under in vitro conditions. The axillary shoots were transferred to media containing $0-600 \mathrm{mM}$ $\mathrm{NaCl}$, and the percentage tissue water content (TWC \%) and fresh weight/dry weight ratio was measured after 30 days of culture. The error bars indicate the SE $(n=3)$. The values are significantly different at $P \leq$ 0.05 , according to least significant difference test (Lokhande et al. 2011a)
Tissue water content (TWC \%)

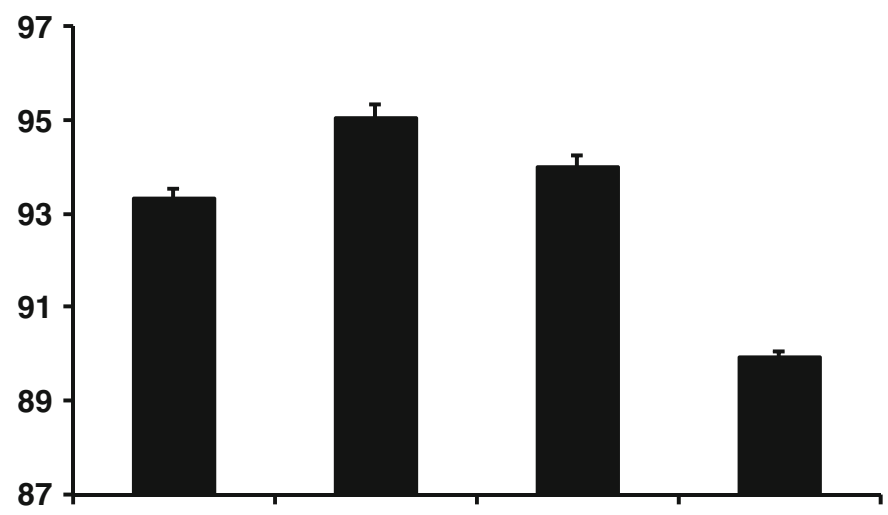

Fresh weight / Dry weight

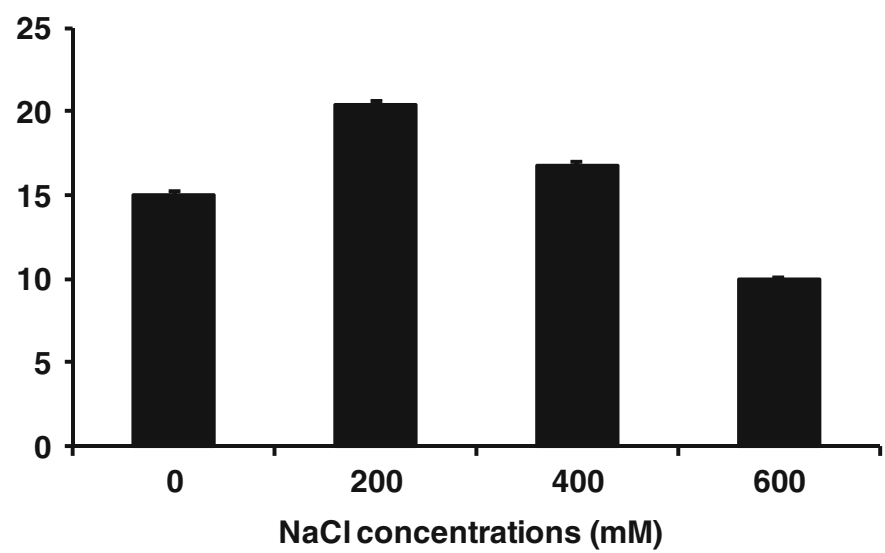

diminished transpiration with improved water use efficiency helps in maintenance of saline ions at sub-toxic level in leaves by decreasing the rate of salt loading into the leaves (Koyro et al. 2006; Liao and Guizhu 2007). An enhanced photosynthetic rate has been observed at 200-900 $\mathrm{mM} \mathrm{NaCl}$ in both whole leaves and mechanically isolated intact mesophyll cells with maximum photosynthetic rate at $600 \mathrm{mM}$ $\mathrm{NaCl}$ (Venkatesalu and Chellappan 1993a). Besides, the increased activity of the whole chain electron transport and photosystem I and II has been observed in isolated chloroplasts at $100-600 \mathrm{mM} \mathrm{NaCl}$ which was lowered at 600 $900 \mathrm{mM} \mathrm{NaCl}$ (Venkatesalu and Chellappan 1993b). Rabhi et al. (2010a) demonstrated the photosynthetic potential of Sesuvium under control (0 mM), moderate $(200 \mathrm{mM})$ and high $(400 \mathrm{mM})$ salinity stress conditions and showed that growth of the plant improved significantly under salinity stress through increased $\mathrm{CO}_{2}$ assimilation rate and enhanced activities of photosynthetic pigments (total carotenoids, $\beta$-carotene, xanthophylls, lutein, neoxanthin and violaxanthin) under salt stress in comparison to nonsaline conditions. Under saline conditions, plants may have a decreased stomatal conductance to avoid water losses and to minimise $\mathrm{Na}^{+}$ions uptake. Consequently, a marked generalised improvement in pigment level and no noticeable alterations in thylakoid proteins at $200 \mathrm{mM}$ $\mathrm{NaCl}$ suggest an increase in the number of photosystems; however, at $400 \mathrm{mM} \mathrm{NaCl}$, the rearrangement of photosystem composition indicated adaptation to the adverse environmental conditions (Rabhi et al. 2010a).

There has also been ambiguity on the behaviour of photosynthetic pathway of Sesuvium in response to abiotic stresses. According to carbon isotope ratio, Sesuvium is categorised as $\mathrm{C}_{3}$ plant (Luettge et al. 1989), while the nitrate reductase activity showed its range between $\mathrm{C}_{3}$ and $\mathrm{C}_{4}$ glycophytes (Bhosale and Shinde 1983a). Despite having aspartate and alanine as the two major products of $\mathrm{CO}_{2}$ fixation, the higher activity of phosphoenol pyruvate carboxylase enzyme than that of ribulose 1, 5biphosphate carboxylase, presence of pyruvate phosphate dikinase enzyme and low activity of NAD-mallic enzyme and NADH-malate dehydrogenase enzymes studies could not classify Sesuvium in the group of $\mathrm{C}_{4}$ plants (Bhosale and Shinde 1983b). The malate concentration ranged between $50 \mathrm{mM}$ (untreated plant) and $150 \mathrm{mM}$ $(856 \mathrm{mM} \mathrm{NaCl})$ with an astonishing increase during light period suggest Sesuvium as a potential $\mathrm{C}_{4}$ plant with $\mathrm{Na}^{+}$ functioning as counter ion to store malate in the vacuoles (Ramani et al. 2006). 


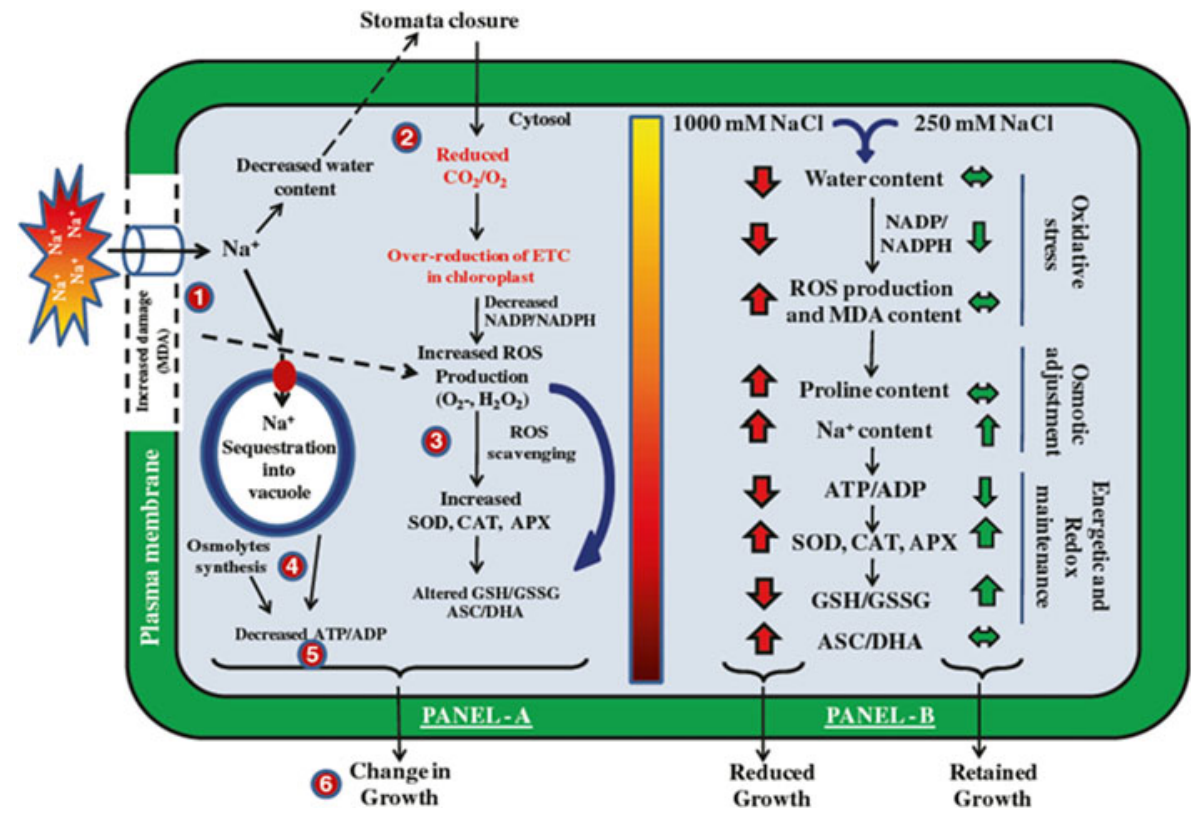

Fig. 4 A generalised scheme for salinity stress responses and biochemical attributes of $S$. portulacastrum exposed to 250 and $1,000 \mathrm{mM} \mathrm{NaCl}$ stress (Lokhande et al. 2011c). a In response to salinity stress, the excess entry of toxic $\mathrm{Na}^{+}$ion disturbs the osmotic balance of the plant cell and induces oxidative damage (1). Simultaneously, salinity imposes water stress and therefore stimulates the stomatal closure, hampers photosynthetic machinery due to altered $\mathrm{CO}_{2} / \mathrm{O}_{2}$ ratio (2). This leads to over-reduction of electron transport chain as a response to decreased NADP/NADPH ratio and in turn to increased generation of reactive oxygen species, which necessitates the increase of enzymatic (SOD, CAT, APX etc.) and non-enzymatic (ascorbate, ASC and glutathione, GSH) antioxidants (3). Plants cells also continue to sequester the $\mathrm{Na}^{+}$ions into the vacuoles as well as to synthesise compatible organic osmolytes (proline, glycine betaine, soluble sugars etc.) (4); however, this process utilises excess amount of energy in the form of ATP, thus affecting the ATP/ADP ratio (5). The cumulative responses of the cell lead to change in the growth in response to salt stress (6); b depicts the responses of halophytic plant $S$. portulacastrum to

\subsection{Ion transport and osmolytes accumulation}

\subsubsection{Mineral ion transport}

Among the mineral ions, $\mathrm{Na}^{+}$ion appears to be the foremost ion and a cheap source of osmoticum to maintain the osmotic balance under abiotic stresses. However, $\mathrm{K}^{+}$plays a major role in the biochemical and physiological processes in plants. Under typical physiological conditions, plant cells require high $\mathrm{K}^{+}(100-200 \mathrm{mM})$ and low $\mathrm{Na}^{+}$(less than $1.0 \mathrm{mM}$ ) and accordingly the high cytosolic $\mathrm{K}^{+} / \mathrm{Na}^{+}$ratio to maintain the osmotic balance (Tester and Davenport 2003) for proper functioning of the cell. $\mathrm{Na}^{+}$competes with $\mathrm{K}^{+}$for intracellular influx as membrane channels transport these cations (Hasegawa et al. 2000; Song et al. 2008). To maintain a high $\mathrm{K}^{+} / \mathrm{Na}^{+}$ratio in the cytosol, plant cells employ primary active transport, mediated by channels and co-transporters for $\mathrm{Na}^{+}$extrusion and/or the intracellular compartmentalisation of $\mathrm{Na}^{+}$in to the vacuole (Blumwald variable concentrations of $\mathrm{NaCl}(250$ and 1,000 $\mathrm{mM}$ ). The arrows in the panel viz., down (down arrow), up (up arrow) and equal (double-side arrow) indicate the negative, favourable and balanced biochemical responses. Thickness of the arrow indicates the extent of change. At $250 \mathrm{mM} \mathrm{NaCl}$ : water status was maintained, NADP/NADPH ratio demonstrated a lower decline, no significant induction occurred in oxidative stress parameters, preferential sequestration of $\mathrm{Na}^{+}$ions occurred, while proline synthesis was not significantly affected, leading to a lower decline in ATP/ADP ratio, antioxidant enzyme activities and the ratio of GSH/ GSSG showed significant increases and the ratio of ASC/DHA remained at par to control; ultimately the growth was parallel to control. In contrast, at $1,000 \mathrm{mM} \mathrm{NaCl}$, water status was negatively affected, NADP/NADPH ratio declined significantly, oxidative stress parameters showed significant increase, high $\mathrm{Na}^{+}$accumulation in addition to stimulated proline synthesis causing significant decline in ATP/ADP ratio, antioxidant enzyme activities and the ratio of ASC/DHA increased but the ratio of GSH/GSSG declined; ultimately resulting in hampered growth

2000). However, under high salt stress, ion ratios are altered by the uncontrolled influx of $\mathrm{Na}^{+}$through $\mathrm{K}^{+}$pathways. $\mathrm{Na}^{+}$ ion accumulation and its sequestration into the vacuole consequently restrict the $\mathrm{K}^{+}$uptake by roots therefore decreasing $\mathrm{K}^{+}$level in the shoots. Though the levels of $\mathrm{K}^{+}$ content were lower in the shoots, Sesuvium can tolerate salt stress at the cost of high potassium use efficiency (KUE) (Messedi et al. 2004; Slama et al. 2008). Besides, biomass analysis showed that the ratio of $\mathrm{K}^{+} / \mathrm{Na}^{+}$was found higher in the roots compared to the shoots and after a certain level of $\mathrm{Na}^{+}$ion accumulation, the roots of this plant may start excluding salt from the roots (Daoud et al. 2001). The presence of electrogenic component in the roots of the plant has also been elucidated but in what way it contributes to the tolerance remains unanswered (Moseki 2007).

Excess accumulation of minerals and salts contribute to increased ash content in $S$. portulacastrum which was found to be higher in the shoots than the roots and increased with increase in salinity (Daoud et al. 2001). The accumulation of 
$\mathrm{Na}^{+}$ions in leaves was reported to be four times higher than in the roots regardless of salt and water-deficit stress (Slama et al. 2006, 2007a, b). While $\mathrm{Na}^{+}$contributes to $18 \%$ of dry weight to equilibrate its concentration, $\mathrm{Cl}^{-}$ions contribute $10-15 \%$ of dry weight in leaves and $10-12 \%$ in the stem (Joshi and Bhosale 1981). It has also been observed that oxalate synthesis stimulated more accumulation of $\mathrm{Na}^{+}$than $\mathrm{Cl}^{-}$ions (Luettge et al. 1989) to maintain the osmotic balance of the cell. Besides the accumulation of $\mathrm{Cl}^{-}$ions, the other negatively charged ions like nitrate $\left(\mathrm{NO}_{3}{ }^{-}\right)$, sulphate $\left(\mathrm{SO}_{4}{ }^{-}\right)$and phosphate $\left(\mathrm{PO}_{4}{ }^{-}\right)$based on the $\mathrm{pH}$ were found to act as counter ions to balance the accumulation of $\mathrm{Na}^{+}$ions (Ramani et al. 2006).

Proteins along with organic acids and amino acids may help to prevent $\mathrm{Na}^{+}$ion toxicity in the vacuole by binding and neutralising charged ions (Ramani et al. 2006). Thus, it is an indirect salt effect (e.g. restriction of $\mathrm{K}^{+}$and nitrogen uptake) rather than direct (high $\mathrm{Na}^{+}$and $\mathrm{Cl}^{-}$accumulation in tissues) that inhibit the growth of the plant in excess salt environment (Messedi et al. 2004). Calcium $\left(\mathrm{Ca}^{2+}\right)$ and magnesium $\left(\mathrm{Mg}^{2+}\right)$ were also found to accumulate in considerable amounts in response to salt stress (Venkatesalu et al. 1994a). The increased uptake of $\mathrm{Ca}^{2+}$ up to $100 \mathrm{mM}$ $\mathrm{NaCl}$ followed by no change in its uptake at high concentration of salt revealed characteristic feature of Sesuvium to avoid inhibition of growth due to high $\mathrm{Ca}^{2+}$ levels as seen in other halophytes (Joshi and Bhosale 1981) and also suggested that $\mathrm{NaCl}$ does not hinder $\mathrm{Ca}^{2+}$ uptake (Messedi et al. 2004). Additionally, a study on calcium signaling and its associated pathways may help understand the role of $\mathrm{Ca}^{2+}$ in Sesuvium under salt stress. Though $\mathrm{Mg}^{2+}$ content was found less than that of $\mathrm{K}^{+}$, the former showed higher concentration in the stem than the leaves, indicating the ion to be partially restrained in the stem and not further transported to the leaves (Joshi and Bhosale 1981). Further, the accumulation of copper, iron, manganese and zinc has also been reported in response to salt stress up to $600 \mathrm{mM} \mathrm{NaCl}$, however the accumulation was found to be decreased at elevated levels of salt (Venkatesalu et al. 1994a).

\subsubsection{Osmolytes accumulation}

Osmotic adjustment under salt stress is an adaptation mechanism operated by both halophytes and glycophytes in order to maintain their water balance (Flowers and Colmer 2008). Besides the accumulation of inorganic ions and its sequestration in the vacuole, the osmotic balance between vacuole and cytoplasm in response to salt stress is through the synthesis of organic solutes to retain the stability of the proteins in cells in response to fall in the water potential of the environment (Zhang et al. 1999). Plants synthesise a variety of organic solutes such as proline, glycine betaine, soluble sugars, polyamines etc., which are collectively called as osmolytes or compatible solutes. These are accumulated to high concentrations within cells without disturbing intracellular biochemistry and cellular functions (Bohnert and Jensen 1996; Cushman 2001). They protect sub-cellular structures, mitigate oxidative damage caused by free radicals (Attipali et al. 2004) and maintain the enzyme activities under salt stress (Yokoi et al. 2002). The osmolytes accumulation is frequently reported in plants including halophytes exposed to salt stress and has been correlated with a plant's capacity to tolerate and adapt to salinity conditions (Errabii et al. 2007; Slama et al. 2008). However, synthesis of these osmolytes is an energydependent process which consumes large number of ATP molecules (Raven 1985), thus affecting the growth.

Plants from the Aizoaceae family accumulate large quantities of proline, an amino acid that often contributes to osmoprotection, when exposed to osmotic stress (Delauney and Verma 1993; Deuschle et al. 2001). Accumulation of proline under various abiotic stresses in Sesuvium indicate that proline plays a key role in osmoregulation to retain its growth potentialities in saline, water-deficit and heavy metal stress conditions (Venkatesalu et al. 1994a, b; Ghnaya et al. 2005, 2007a,b; Slama et al. 2006, 2007a, b, 2008; Lokhande et al. 2010a, b, c, 2011a, b; Moseki and Buru 2010). When compared to other plants, $S$. portulacastrum appeared as a high proline accumulator, with proline levels reaching $300 \mu \mathrm{mol} \mathrm{g}^{-1}$ leaf dry matter (Slama et al. 2006).

Besides proline, higher salinity also causes increased accumulation of glycine betaine (Venkatesalu et al. 1994a, b; Lokhande et al. 2010b, c) (Fig. 5a). The accumulation of glycine betaine was assumed to have positive functions in relation to maintenance of membrane integrity and stability of other cellular structures under salt and drought stress conditions (Wang and Showalter 2004; Martinez et al. 2005). It is widely believed that synthesis and accumulation of glycine betaine protects cytoplasm from ion toxicity, dehydration and temperature stress (Rhodes and Hanson 1993; Subbarao et al. 2001b). In addition, glycine betaine aids in normal functioning of the metabolic machineries in the cell during stress conditions by stabilising macromolecule structures, protecting chloroplast and photosynthesis system II (PS II) by stabilising the association of the extrinsic PS II complex proteins and indirectly interacting with phosphatidylcholine moieties of membranes to alter their thermodynamic properties (Subbarao et al. 2001b; Ashraf and Harris 2004) to maintain the membrane integrity during stress. The accumulation of glycine betaine under salinity stress for adaptation in Sesuvium has been well documented, though mechanism of its production and control is yet to be studied. The phytoconstituents trans-4-hydroxyprolinebetaine and 3, 5, 4-trihydroxy-6, 7-dimethoxyflavone 3-glucoside found in Sesuvium have also been thought to have role in osmotic tuning (Adrian-Romero et al. 1998).

Despite involvement of proline and glycine betaine in osmotic adjustment, complete osmotic balance between the 
Fig. 5 Accumulation of osmolytes at different salt concentrations. Axillary shoots of Sesuvium were transferred to media containing $0-600 \mathrm{mM}$ $\mathrm{NaCl}$ and measurements were made for (a) proline, glycine betaine, and (b) total soluble sugars after 30 days of culture. The error bars indicate the SE $(n=3)$. The values are significantly different at $P \leq 0.05$ (Lokhande et al. 2011a) a Proline, Glycine betaine $\left(\mu \mathrm{g} \mathrm{g}^{-1} \mathrm{FW}\right)$

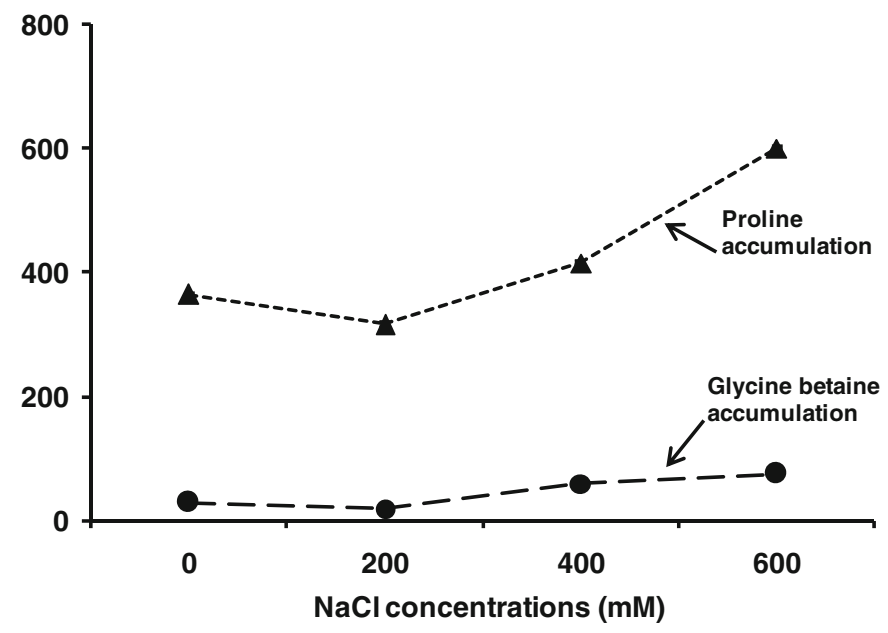

\section{b Total soluble sugars $\left(\mathrm{mg} \mathrm{g}^{-1} \mathrm{FW}\right)$}

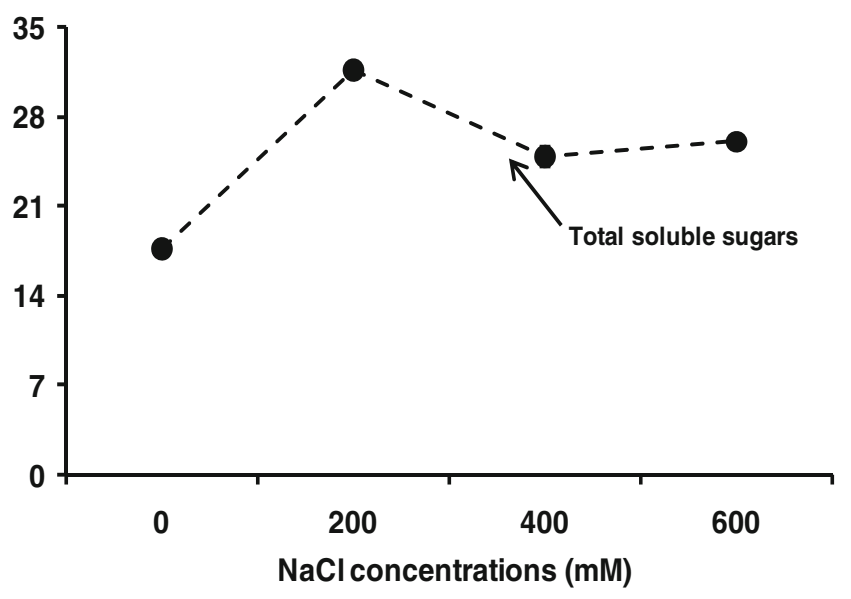

vacuole and cytoplasm requires accumulation of organic compounds such as soluble sugars (Pagter et al. 2009). The total soluble sugar content was observed to increase with $\mathrm{NaCl}$ concentration up to $200 \mathrm{mM}$ with a marginal decrease thereafter (Venkatesalu et al. 1994a; Slama et al. 2007a, b; Lokhande et al. 2010b, c, 2011a) (Fig. 5b). It is imperative to understand the relationship between the quantity of total soluble sugars and salinity as this will aid in understanding whether this change in content of sugars is due to (1) stress-induced modifications of photosynthesis, (2) activation of sucrose-phosphate-synthase activity by osmotic stress (Toroser and Huber 1997) or (3) yet to be elucidated role of sugars in salinity stress..

\subsection{Tolerance to oxidative stress}

Oxidative stress is a secondary manifestation of stress probably due to inhibition of PS II (Blumwald et al. 2004) affecting the photosynthetic capacity. An apparent cause for decrease in photosynthetic capacity may be due to a decrease in $\mathrm{CO}_{2} / \mathrm{O}_{2}$ ratio correlated with closure of stomata at peak irradiance increasing the probability of electron transfer from chlorophyll- $a$ in its triplet state to molecular oxygen $\left(\mathrm{O}_{2}\right)$ leading to an increase in generation of reactive oxygen species (ROS) (Ramani et al. 2006). The oxidative stress is counteracted by antioxidant activities of higher concentrations of polyphenols. However, the 2,2-diphenyl1,1-picrylhydrazyl free radical scavenging assay against $\alpha$ tocopherol method for polyphenols suggested that the antioxidant activities of polyphenols were not found very potent in S. portulacastrum (Agoramoorthy et al. 2008) and there might be another scavenging system for detoxification of free radicals to reduce the oxidative stress. It is possible that proline may be contributing to the active non-enzymatic antioxidant system for an efficient scavenging of ROS, as findings of proline as a reducing agent for oxidative stress induced by osmotic stress have been reported (Hong et al. 2000). A conspicuous decrease in proline has been observed during summer (Joshi and Bhosale 1981) when the plant suffers from both types of abiotic stresses concomitantly increasing oxidative stress. There might also be a possibility of glutathione-ascorbic acid (GSH-ASC) system existing to 
combat oxidative stress, which was based on the presence of high levels of glutamic acid in the stem during summer (Joshi and Bhosale 1981). Furthermore, the osmolytes (proline and glycine betaine) accumulation also has been suggested to have a role in detoxification of reactive oxygen species (Ashraf and Harris 2004; Szabados and Savoure 2009). The presence of flavonoids and polyphenols in Sesuvium has also been suggested for their role in protection from UV stress and pathogen attack (Heldt 2005; Agoramoorthy et al. 2008).

Another facet of oxidative stress tolerance mechanism is through the activation of efficient enzymatic antioxidant systems such as catalase (CAT), ascorbate peroxidase (APX), superoxide dismutase (SOD), guaicol peroxidase etc., which regulate the levels of ROS, maintain the signaling of ROS and thus protect the plant from the oxidative damage. Understanding key components of enzymatic antioxidant machinery involved in scavenging ROS and maintenance of higher redox state of the Sesuvium at various levels of tissue organisation need to be addressed.

\subsection{Redox homeostasis and energetic status}

The increasing data on the mechanism of salinity tolerance in halophytes has suggested the coordinated action of number of physiological, biochemical and molecular processes occurring in plants to combat the stress condition and to maintain the homeostasis. The ratios of $\mathrm{NADPH} / \mathrm{NADP}^{+}, \mathrm{NADH} / \mathrm{NAD}^{+}$and adenosine $5^{\prime}$-triphosphate/adenosine $5^{\prime}$-diphosphate (ATP/ADP) increased in the drought-stressed plants, suggesting that an upregulation of the reduced redox state and the energy supply in the plant cells might be important strategy for plants responding to drought stress (Chen et al. 2004). However, there is no information available on the maintenance of redox balance and energetic status of halophytes, which supposedly are the key regulators of their adaptation and survival under high salt stress conditions. Recently, Lokhande et al. (2011c) demonstrated that regulation of various enzymatic and non-enzymatic antioxidants and redox couples are key players in maintenance of redox state in salt-stress-tolerant Sesuvium. Experimental evidence show that plants exposed to $250 \mathrm{mM} \mathrm{NaCl}$ demonstrated regulated growth through preferential accumulation of sodium ions $\left(\mathrm{Na}^{+}\right)$over proline, and maintained the ratios of NADP/NADPH and ATP/ADP at par to control. Increased antioxidant enzyme activities and the ratio of reduced/oxidised glutathione (GSH/GSSG) and reduced to oxidised ascorbate ratio (ASC/DHA) further helped to reduce the oxidative stress. However, plants subjected to $1000 \mathrm{mM} \mathrm{NaCl}$ revealed adverse effects on the growth due to uncontrolled decline in the ratios of NADP/NADPH and ATP/ADP and energyconsuming metabolite synthesis (i.e. proline) irrespective of increased enzyme activities as compared to control. This was the first evidence that demonstrated a mechanistic insight of the effect of high salt concentration on the energetic and redox status of a halophyte which affects its growth parameters (Fig. 6).

\subsection{Other mechanisms of stress tolerance}

\subsubsection{Role of ATPases}

The main tenet of salinity stress is to avoid cytosolic salt toxicity, which requires energy requiring for an efficient working of ATPase machinery. Physiological adaptation to salt stress existing in roots to reduce the transport of toxic ions to leaves is a plausible explanation for the lack of difference in the plasma membrane $\mathrm{H}^{+}$-ATPase activity in control and saltstressed plants and also in the vacuolar ATPase activity in the vacuoles and F-ATPase activity in the chloroplast and mitochondria (Ramani et al. 2006). Such an unchanged status in enzymatic activities is difficult to explain but it is assumed that increased sulpholipid content may help plant to stabilise the thylakoid protein complexes showing no change in F-ATPase functioning (Minoda et al. 2003). Additionally, the ability of the plant to exchange vacuolar $\mathrm{K}^{+}$with cytoplasmic $\mathrm{Na}^{+}$ (Slama et al. 2008) may further explain the lack of effect of stress on V-ATPase activity. Other plausible explanation for lack of V-ATPase activity may be that Sesuvium being succulent halophyte having a large vacuole uses saline ions as cheap osmolytes to maintain osmotic balance in the cell thus avoiding over-consumption of energy or diversion of energy for other activities (Ramani et al. 2006).

Subsequent to salt stress, halophytes have the potential to adjust P-type ATPase activity to the control rate within 8 days (Huchzermeyer1 et al. 2004). Salt-tolerant plants also possess active tonoplast $\mathrm{Na}^{+} / \mathrm{H}^{+}$antiporter proteins conferring salt tolerance (Binzel and Ratajczak 2002), however, the presence of this protein in Sesuvium is yet to be elucidated. Studies on ATPases and antiporter protein under salinity stress are yet to be demonstrated to provide clues and insight into the tolerance mechanism.

\subsubsection{Sulphur metabolism}

Apart from the sequestration and synthesis of osmolytes for the maintenance of osmotic balance between cytoplasm and vacuole, Sesuvium shows good adaptation and management under extreme environmental conditions through modified nutrient metabolism. Salt stress management is an energydemanding process which requires high amount of ATP production and its utilisation to maintain the osmotic balance, and it has been observed that sulpholipids play a vital 


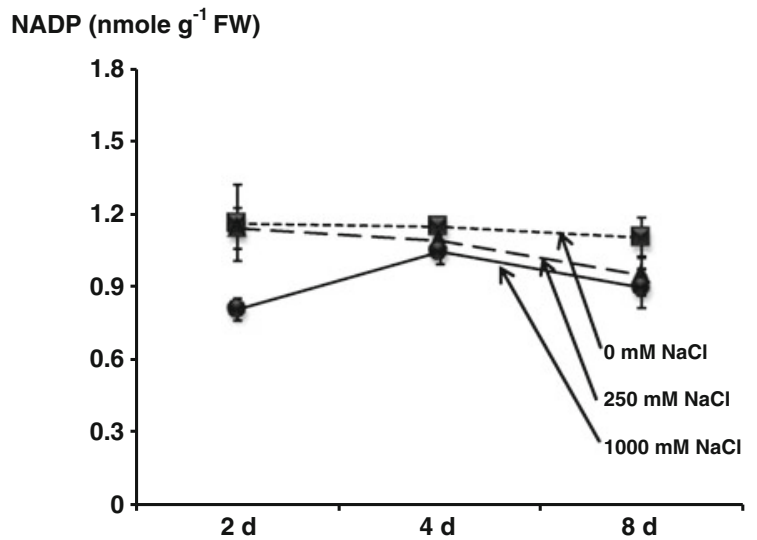

NADPH (nmole $\left.\mathrm{g}^{-1} \mathrm{FW}\right)$

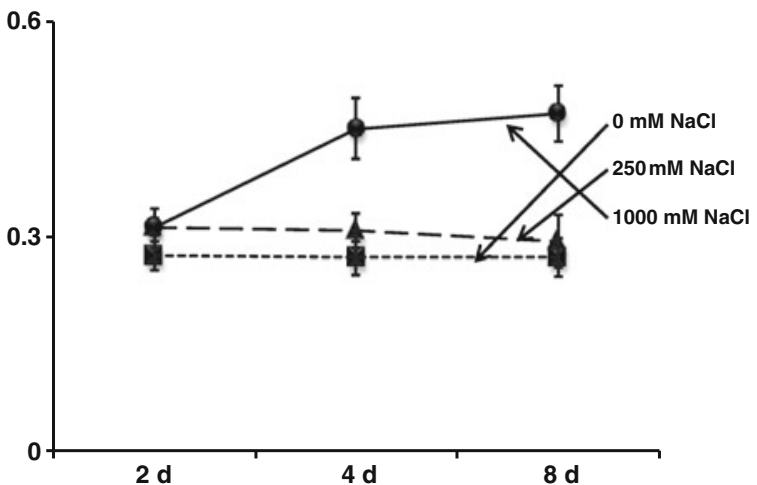

NADP / NADPH ratio

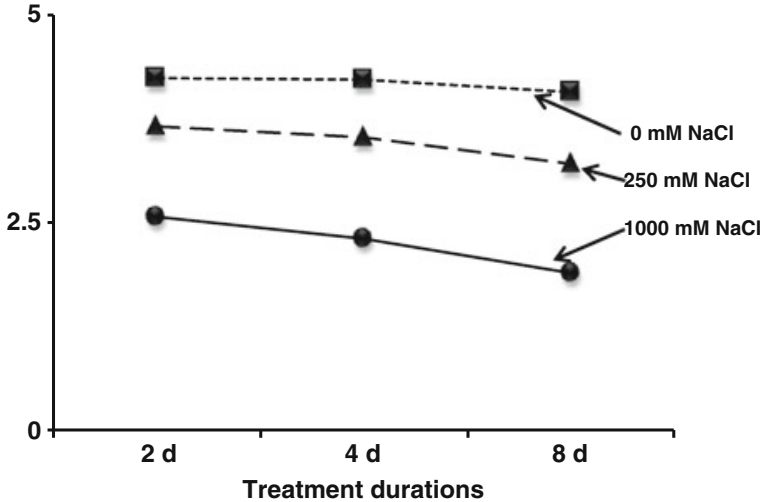

Fig. 6 Time-dependent measurement of NADP, NADPH, NADP/ NADPH ratio, ATP, ADP and ATP/ADP ratio in $S$. portulacastrum plants upon exposure to $\mathrm{NaCl}$. All values represent the mean of three

role for ATP formation within chloroplast membranes and stabilisation of the photosystems (Krupa and Bazynski 1977). Significantly, the higher content of sulpholipids and sulphoquinovosyldiacylglycerol (SQDG) containing predominantly the palmitic acid, $\gamma$-linolenic acid and trace amounts of linoleic acid in the salt-stressed shoots of Sesuvium revealed their active participation in salt stress tolerance (Ramani et al. 2004a, b). This sulpholipid is localised in the thylakoid membranes and is known to be stabilising
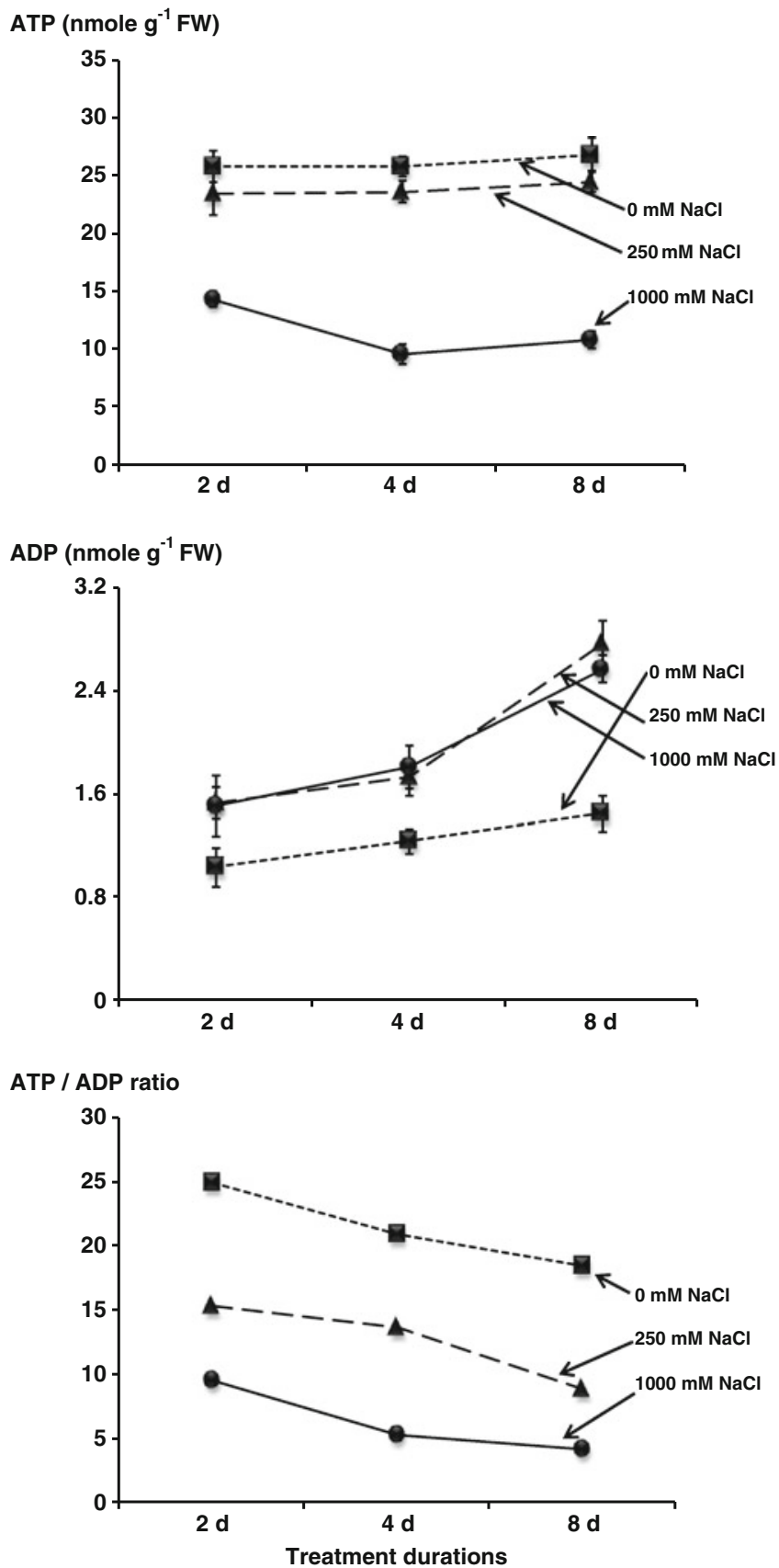

replicates \pm standard error significantly different at a particular duration $(P \leq 0.05)$ (Lokhande et al. 2011c)

protein complexes in the chloroplast membranes such as photosystem II (Minoda et al. 2003). Further, it has been observed that the unsaturation of SQDG varied with a change in duration and amount of salt stress (Ramani et al. 2004a, b). The unsaturated fatty acids in membrane lipids enhance the tolerance of photosystem II to salt stress, and hence this could contribute to improved salt stress tolerance. Whether such a mechanism is operative in Sesuvium requires further investigation. 


\subsubsection{Amino acids and fatty acids metabolism}

High salinity leads to disturbance in nitrogen metabolism consequently affecting protein synthesis leading to accumulation of free amino acids (Strogonov 1973). Interestingly, the amino acid levels in Sesuvium plants exposed to salt stress declined significantly with increasing $\mathrm{NaCl}$ concentrations; however, with increase in the duration of salt stress exposure, the levels of amino acid and protein was found to have increased (Venkatesalu et al. 1994b). The levels of proline, aspartic acid, glutamic acid, alanine, serine and glycine were found higher as compared to other amino acids in the succulent stem and leaves of S. portulacastrum (Joshi and Bhosale 1981). Noticeable seasonal variations have also been observed in the amino acid pool of different plant parts wherein the total quantity of amino acids decreased in the leaves in summer and the reverse was found true in the stem. A conspicuous decrease in proline as against the increased concentrations of aspartic acid, glutamic acid, alanine, valine and leucine has been reported in summer season (Joshi and Bhosale 1981). However, it is difficult to explain the seasonal influence on proline content because Venkatesalu et al. (1994b) and Slama et al. (2008) have reported that $S$. portulacastrum under salt stress alone or in combinations with water-deficit stress accumulated higher levels of proline and contributed to osmotic tuning. Further, a confirmatory link has been observed between maintenance of growth, tissue hydration and proline accumulation in leaves during osmotic stress (Slama et al. 2007b).

Proline has been reported to protect quaternary structures of protein from denaturing, stabilise cell membrane by interaction with phospholipids, act as antioxidants and may serve as an energy and nitrogen source (Sen et al. 2001; Slama et al. 2007a). Proline is synthesised through glutamate or ornithine and in Sesuvium, it has been established that under water-deficit stress an increased ornithineaminotransferase activity plays a role in proline synthesis, while reduced proline dehydrogenase activity contributes to protein catabolism (Slama et al. 2006). It will be intriguing to study the ornithine and glutamate pathways contributing to proline accumulation and synthesis to deal with osmotic adjustment. This physiological adaptation to survive and avoid osmotic death may be attributed to increased pyrroline-5-carboxylate reductase activity which is involved in proline synthesis (Treichel 1986), or restriction of incorporation of this amino acid into protein, or an inhibition of its transformation into glutamate and arginine (Joshi and Bhosale 1981), or salt-induced inhibition of pyrroline-5carboxylate dehydrogenase (Huber 1974) or removal of feedback inhibition of enzyme involved in protein biosynthesis like $\Delta^{1}$-pyrroline-5-carboxylate synthetase (Hong et al. 2000). Further studies are warranted to characterise the metabolome and metabolic agility of this plant under osmotic and ionic stress conditions. Besides amino acids, the fatty acid profile showed accumulation of myristic, palmitic, stearic, oleic, linoleic and linolenic acids as key fatty acids and campesterol, stigmasterol and sitosterol as major sterols in the leaves.

\subsection{Tolerance to heavy metals}

Sesuvium has shown tolerance against a variety of toxic heavy metals (Table 1$)$. In general, cadmium $\left(\mathrm{Cd}^{2+}\right)$ accumulation in the vegetative parts of the plant induces chlorosis, necrosis and growth inhibition; however, experimental evidence demonstrated a higher accumulation of $\mathrm{Cd}^{2+}$ in roots as compared to shoots of Sesuvium and further suggested the plant as a hyper-accumulator based on the concentrations detected in the shoots (Ghnaya et al. 2007b). Besides, the growth characteristics of the Sesuvium exposed to $\mathrm{Cd}^{2+}$ were found to be improved in combination with $\mathrm{NaCl}$ in comparison to $\mathrm{Cd}^{2+}$ alone, wherein growth inhibition was recorded and was correlated with the disturbance in $\mathrm{Ca}^{+}$nutrition (Ghnaya et al. 2007b). This may be ascribed to "competition theory between the two cations $\left(\mathrm{Ca}^{2+}\right.$ and $\left.\mathrm{Cd}^{2+}\right)$ during influx" as seen in Arabidopsis (Ghnaya et al. 2007a). The apoplastic uptake is relatively non-selective between divalent cations which mean that toxic substances such as $\mathrm{Cd}^{2+}$ also may pass into the plant (White and Broadley 2003). Therefore, studies are required to investigate whether increase in concentration of $\mathrm{Ca}^{2+}$ in culture medium containing $\mathrm{Cd}^{2+}$ or $\mathrm{Cd}^{2+}$-polluted saline soil would enhance the growth ability of the plant and $\mathrm{Cd}^{2+}$ phyto-extraction capacity of the plant. Furthermore, the circuitous effect of $\mathrm{Cd}^{2+}$ on $\mathrm{K}^{+}$ uptake probably due to "complexing ATP and reduction of energy availability" (Aspe et al. 1994) may explain the reduced absorption and translocation of $\mathrm{K}^{+}$- in $\mathrm{Cd}^{2+}$-stressed plants. The increase in KUE, ability of $\mathrm{Na}^{+}$to replace $\mathrm{K}^{+}$for a specific functions with no adverse effect on growth in presence of $\mathrm{NaCl}$ and $\mathrm{Cd}^{2+}$ suggests that $\mathrm{K}^{+}$does not act as a limiting nutrient for growth in $\mathrm{Cd}^{2+}$-stressed plants (Ghnaya et al. 2007a,b). Similarly, restriction on N uptake does not hinder growth in such stressed plants (Ghnaya et al. 2007a,b). It has been observed that $\mathrm{NaCl}$ alleviated the toxic effect of $\mathrm{Cd}^{2+}$ stressed plants and retained growth by enhancing $\mathrm{Cd}^{2+}$ transportation which may be attributed to "uptake and translocation of both complexed forms $\left(\mathrm{CdCl}\right.$ and $\left.\mathrm{CdCl}_{2}\right)$ and increased availability of inorganic $\left(\mathrm{Cl}^{-}\right)$and organic (oxalate) anions for $\mathrm{Cd}^{2+}$ complexation and transport" (Ghnaya et al. 2007a). Further, the authors ascribed the lower content of $\mathrm{Cd}^{2+}$ in the plants exposed to $\mathrm{NaCl}$ in combination with $\mathrm{Cd}^{2+}$ (as compared to $\mathrm{Cd}^{2+}$ alone) due to "biological dilution of $\mathrm{Cd}^{2+}$ by growth" and change in translocation factor which increases with increase in $\mathrm{NaCl}$ concentration in medium, with the highest translocation factor at $400 \mathrm{mM} \mathrm{NaCl}$. 
Table 1 Effects of heavy metal/toxic compounds on the growth or accumulation in Sesuvium portulacastrum

\begin{tabular}{|c|c|c|c|}
\hline $\begin{array}{l}\text { Heavy metal/toxic } \\
\text { compound }\end{array}$ & $\begin{array}{l}\text { Nutrient medium }(\mathrm{NaCl} \\
\text { and heavy metal) }\end{array}$ & Response & Reference \\
\hline \multirow[t]{4}{*}{ Cadmium $\left(\mathrm{Cd}^{2+}\right)$} & $\begin{array}{l}\mathrm{NaCl}(100 \mathrm{mM}) \text { and } \mathrm{CdCl} 2 \\
\quad(0,50,100,200 \text { and } 300 \mathrm{mM})\end{array}$ & $\begin{array}{l}\mathrm{Cd}^{2+} \text { accumulation was significantly higher in the } \\
\text { roots than in the shoots }\left(350-700 \mathrm{mg} \mathrm{g}^{-1} \text { dry matter) }\right.\end{array}$ & Ghnaya et al. 2005 \\
\hline & $\mathrm{Cd}^{2+}(100 \mu \mathrm{M})$ & $\begin{array}{l}\mathrm{K} \text { and } \mathrm{Ca} \text { uptake was impaired in roots exposed to } \mathrm{Cd}^{2+} \\
\text { whereas } \mathrm{N} \text { uptake was not affected. } \mathrm{Cd}^{2+} \text { limits growth } \\
\text { of both halophytes through restriction imposed on } \mathrm{Ca}^{2+} \\
\text { uptake. Increased } \mathrm{Ca}^{2+} \text { availability in the soil will help } \\
\text { to improve the growth of the plants and for extraction } \\
\text { of } \mathrm{Cd}^{2+} \text { from contaminated soils }\end{array}$ & Ghnaya et al. $2007 \mathrm{a}$ \\
\hline & $\begin{array}{l}50 \text { or } 100 \mu \mathrm{M} \mathrm{Cd}^{2+} \text { alone or } \\
\text { combined with } 100 \text { or } 400 \\
\mathrm{mM} \mathrm{NaCl}\end{array}$ & $\begin{array}{l}\mathrm{Cd}^{2+} \text { treatments induced chlorosis, necrosis, inhibited plant } \\
\text { growth and reduced } \mathrm{K}^{+} \text {and } \mathrm{Ca}^{2+} \text { uptake and transport to } \\
\text { the shoots. Addition of } \mathrm{NaCl} \text { to } \mathrm{Cd}^{2+} \text { containing medium } \\
\text { restored the growth and enhances the amount of } \mathrm{Cd}^{2+} \\
\text { accumulation in the shoots }\end{array}$ & Ghnaya et al. 2007b \\
\hline & $\begin{array}{l}\mathrm{Cd}^{2+}(0,50,100 \text { and } 200 \mu \mathrm{M}) \\
\quad \text { for } 30 \text { days }\end{array}$ & $\begin{array}{l}\text { Significant reduction in the contents of total lipids (TL) and } \\
\text { lipid fractions including galactolipids (GL), phospholipids } \\
\text { (PL) and neutral lipids (NL) }\end{array}$ & Nouairi et al. 2006 \\
\hline \multirow[t]{2}{*}{ Lead $\left(\mathrm{Pb}^{2+}\right)$} & $\begin{array}{l}0,200,400,800 \text { and } 1,000 \mu \mathrm{M} \\
\mathrm{Pb}^{2+} \text { for } 21 \text { days }\end{array}$ & Accumulated more $\mathrm{Pb}^{2+}$ in the shoots & Zaier et al. $2010 \mathrm{~b}$ \\
\hline & & $\begin{array}{l}\text { Presence of phytochelatin isoform } \mathrm{PC} 3 \text { in the extracts. } \\
\text { Effective accumulation and redistribution of } \mathrm{Pb}^{2+} \text { from } \\
\text { root to shoot }\end{array}$ & Zaier et al. 2010a \\
\hline Arsenic (As) & $\mathrm{As}(\mathrm{V})(100-1,000 \mu \mathrm{M})$ & Significant As accumulation ( $155 \mu \mathrm{g} \mathrm{g}^{-1}$ dry weight $)$ & Lokhande et al. $2011 \mathrm{~b}$ \\
\hline $\begin{array}{l}\text { Green HE4B (toxic } \\
\text { textile dye) }\end{array}$ & $\begin{array}{l}\text { GHE4B }\left(50 \mathrm{mg} \mathrm{l}^{-1}\right) \text { in presence } \\
\text { of } 200 \mathrm{mM} \mathrm{NaCl}\end{array}$ & $\begin{array}{l}\text { Efficient phytotransformation of GHE4B; efficient } \\
\text { degradation of textile dyes and its efficacy on saline } \\
\text { soils contaminated with toxic compounds }\end{array}$ & Patil et al. 2012 \\
\hline
\end{tabular}

The Sesuvium leaves under $\mathrm{Cd}^{2+}$ stress showed unchanged fatty acid composition of total membrane lipids which was plausibly accredited to efficient antioxidant system against metal-induced oxidative stress (Nouairi et al. 2006). The exact physiological adaptation to metal stress and fate of accumulated $\mathrm{Cd}^{2+}$ in Sesuvium whether it is subcellular localised or sequestered by metallothionine or phytochelatin or proline is yet be elucidated. The ability of this plant to take up uranium, strontium, cesium and europium from their aqueous solutions with its maximum uptake in roots followed by stem and leaves makes Sesuvium a potential bioremediation plant (Thulasidas et al. 1999).

Zaier et al. (2010a) compared lead $\left(\mathrm{Pb}^{2+}\right)$ accumulation and redistribution ability between Sesuvium and Brassica juncea and found that unlike Brassica, Sesuvium's nutrient uptake was not affected in presence of $1,000 \mu \mathrm{M} \mathrm{Pb}^{2+}$ and additionally the latter species could accumulate $3,400 \mu \mathrm{g} \mathrm{g}^{-1}$ $\mathrm{DW}$ of $\mathrm{Pb}^{2+}$ in shoots. Therefore, suggesting $S$. portulacastrum as an efficient $\mathrm{Pb}^{2+}$ extractor. Studies by Zaier et al. (2010b) revealed presence of phytochelatin 3 (PC3) as the bioligand responsible for metal binding and detoxification of lead thus suggesting the application of Sesuvium and Brassica for phytoremediation of lead.

Recent studies by Lokhande et al. (2011b) showed no or slight changes in metabolites (total non-protein thiols and cysteine) and enzymes (serine acetyltransferase, cysteine synthase and $\gamma$-glutamylcysteine synthetase) of thiol metabolism during exposure of Sesuvium to arsenic (As) suggesting its ability to tolerate high As concentrations (Fig. 7). Additionally, based on total As accumulation, bioaccumulation factor and known biomass production capacities, Sesuvium like other As hyper-accumulator plants can be used as potential candidates for application in arsenic removal and land re-vegetation/reclamation projects in the As-contaminated sites of the world.

In general, to cope with toxic heavy metals, plants activate the sulphur assimilation pathway by increasing transcription of related genes to provide an enhanced supply of glutathione for phytochelatin biosynthesis (Harada et al. 2002). A similar generalisation may be proposed for Sesuvium to understand the response of sulphur assimilation pathway enzymes in phytoremediation.

\section{Molecular studies}

Plant adaptation to environmental stresses is controlled by cascades of molecular networks. In this regard, the application of genomic technologies has made more impact on understanding the plant responses to the abiotic stresses (Cushman 2003). On the genomics front, early efforts have been made to construct cDNA libraries of $S$. portulacastrum to enable identification of salt tolerance genes (Zeng et al. 2006). This study revealed a full-length gene in clone $P 152$ with a predicted 344 amino acid residues having a late 
Arsenic (As) accumulation $\left(\mu \mathrm{g} \mathrm{g}^{-1} \mathrm{DW}\right)$

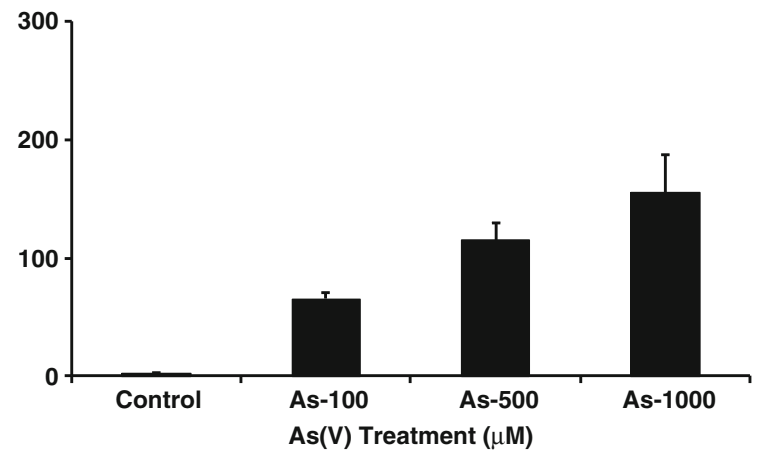

Fig. 7 Arsenic accumulation in plants of S. portulacastrum. All values are means of triplicate $\pm \mathrm{SD}$. ANOVA significant at $P \leq 0.05$ (Lokhande et al. 2011b)

embryogenesis abundant- 2 protein domain, a signature motif for proteins that have been enriched under salt or drought conditions. Fan et al. (2009) isolated a fructose-1,6-bisphosphate aldolase gene (FBA) from differentially expressed cDNA library of Sesuvium roots exposed to seawater by using the suppressive subtractive hybridisation ( $\mathrm{SSH}$ ) approach and designated it as $S p F B A$. The precursor protein encoded by $S p F B A$ is predicted to be FBA localised in the cytoplasm of cell and its expression is suggested to be involved in response to different abiotic stress stimuli such as seawater, $\mathrm{NaCl}$, abscisic acid and PEG. In addition, the over-expression of SpFBA gene in Escherichia coli under salt stress also demonstrated ability to survive under salt stress conditions suggesting important roles in responding to salt stress and related abiotic stimuli.

Biological responses and developmental processes of the plants are precisely controlled at the gene expression levels and information on the temporal and spatial regulation of gene expression often sheds light on the potential function of a particular gene. As not much information is available on the sequences of Sesuvium, the projects on use of cDNAamplified fragment length polymorphism or SSH tools for the synthesis of enriched cDNA library under adverse abiotic stress conditions (salinity, drought and heavy metal) will help to generate exhaustive information on expression profiling of different transcriptomes under these stresses. Furthermore, the information will resolve the specific molecular mechanism underlying abiotic stress tolerance in this species.

\section{Biotechnological implications}

Established protocols of tissue culture should enable largescale production of plants for its conservation and also to cover the barren lands for greenification and in saline areas for desalination purpose. For conservation of the species and taking into account the approach of large-scale multiplication,
Kathiresan et al. (1997) and Lokhande et al. (2010a) successfully developed efficient protocols for micropropagation and callogenesis using axillary shoots. The highest rate of shoot induction was obtained using MS (Murashige and Skoog 1962) medium and a combination of high cytokinin and/or low auxin. Root induction from the established shoots, was achieved on MS liquid medium containing $\alpha$ naphthaleneacetic acid, whereas the rooted plantlets exhibited $85 \%$ survival in field conditions (Lokhande et al. 2010a). The callus can be used for the establishment of cell suspension cultures, which could act as a source for the synthesis and production of valuable secondary metabolites such as 20hydroxyecdysone (20E) (Lokhande et al. 2010a). In addition, different precursors and elicitors (biotic and abiotic) can be used in cell suspension culture for enhanced production of secondary metabolites on large scale under control conditions.

Salt stress studies are preferably conducted in soil-less culture with nutrient solutions of known salt concentrations (Vijayan et al. 2003) because, at the field level, the salinity levels vary depending on the season and soil depth (Daniells et al. 2001) and the enormous potential for interactions with other environmental factors (Pe'rez-Tornero et al. 2009). In this regard, the use of cell and tissue culture facilitate to study salt tolerance mechanism at the unorganised cellular or organised tissue level, and may provide information on the physiological, biochemical and growth responses to salt stress at different levels of tissue organisation. Besides, in vitro studies allow relatively faster responses; shorter generation time and controlled environment as compared to ex vitro conditions (Zhang et al. 2004; Pe'rez-Tornero et al. 2009) and the inferences obtained from in vitro cultures under salt stress may be directly applicable at the whole-plant level. Lokhande et al. (2010b, c, 2011a) recently studied the potential of Sesuvium callus and axillary shoot cultures to tolerate and survive under in vitro salt stress conditions in terms of growth, physiological and biochemical changes. These studies revealed that cell cultures exhibited poor survival under stressed conditions as compared to axillary shoots, at the expense of reduced growth of the calli, lower antioxidant enzyme activities and significantly higher accumulation of inorganic ions and osmolytes. However, the tolerance capacity was found significantly higher in the axillary shoot cultures exposed to $200 \mathrm{mM} \mathrm{NaCl}$. The physiological and biochemical analyses showed difference in response of callus culture to osmotic and ionic stress as compared to response seen for these stresses at whole plant level (Lokhande et al. 2010c). Nabikhan et al. (2010) employed callus and leaf extracts of Sesuvium as substrates for successful production of antimicrobial silver nanoparticles using silver nitrate $\left(\mathrm{AgNO}_{3}\right)$. The study revealed that callus extracts are more suitable for the production of silver nanoparticles than the leaf extracts. The uses of plants for nanoparticle synthesis is more beneficial because the particles are produced extracellularly; however, studies using plant 
systems for the production of these nanoparticles are very limited. Thus, eco-friendly, cost-effective and biological system-based technology using biotechnological (tissue culture) approach should make it possible for the synthesis of various kinds of antimicrobial compounds from the plants and its production on a large scale for pharmaceutical applications.

In the author's laboratory, hairy root cultures were established from in vitro grown leaf and axillary shoot explants of Sesuvium (Fig. 8). The explants co-cultivated with bacterial strain Agrobacterium rhizogenes ATCC 5140 showed successful induction of hairy roots with 70 and $50 \%$ root induction frequency in leaf and axillary shoot explants, respectively. High biomass production using hairy roots assumes significance for the synthesis of valuable secondary metabolites. The established hairy root cultures of Sesuvium will boost the production of 20-hydroxyecdysone in addition to synthesis of some novel compounds within a short time under control conditions. Furthermore, treatments with precursors or elicitors will also be useful to augment higher secondary metabolite $(20 \mathrm{E})$ production.

\section{Metabolites}

Sesuvium is an important source of phytoecdysteroids (insect molting hormones) 20-hydroxyecdysone along with the minor amount of ecdysone, which regulates many biochemical and physiological processes during the various developmental stages of insects (Simon and Krolman 1989). The steroid hormones affects pupation in insects and thus these phytoecdysones can probably be used as biological pesticides. One of the most important applications of $20 \mathrm{E}$ is in the agriculture-based sericulture industry to significantly elevate the yield of silk obtaining from the cocoon (Chou and Lu 1980; Ninagi and Maruyama 1996; Dinan 2001). For this purpose, the silkworm larvae, Bombyx mori, are exogenously treated with $20 \mathrm{E}$ at certain stages of development which results into early transfer of larvae to the cocoon spinning devices and simultaneous and synchronised cocoon formation. Of the various Chinese plant sources identified, Sesuvium contained the highest levels of ecdysteroids and can be used in sericulture industry to manage the silkworm rearing during the last stage of larval development (Wong et al. 1979; Chou and Lu 1980; Nair et al. 2005).

In the biomedical application, 20E and derivatives are used for health improvement as they have been shown to stimulate the synthesis of proteins, builds muscle, be adaptogenic for human immunodeficiency virus (HIV) patients and have antioxidant and tonic properties (Bathori 2002; Sinlaparaya et al. 2007). The ready availability of $20 \mathrm{E}$ from plant sources has led to a boom in recent years in its inclusion in many commercial anabolic preparations for body-builders and sportsmen (Dinan and Lafont 2006; Sinlaparaya et al. 2007). 20E has significant spermicidal activity (Bandara et al. 1989) and influence the sexual activity of male rats (Mirzaev and Syrov 1992). A number of reports suggested that ecdysteroids may be effective in the control of diabetes (Yoshida et al. 1971; Uchiyama and Yoshida 1974; Najmutdinova and Saatov 1999; Dinan 2001). The importance of $20 \mathrm{E}$ in the agricultural and biomedical fields generates great interest for their extraction from a variety of plants species to enhance production of $20 \mathrm{E}$ at industrial scale. Approximately $6 \%$ of plant species have been identified for the presence of $20 \mathrm{E}$ which was much higher than those present in arthropods (Dinan 2001; Klein 2004). However, very little information is available on the large-scale production of 20-hydroxyecdysone using the potential sources of 20E, such as Sesuvium, which grows along the coastal regions of the world. Therefore, efforts should be made in this direction to adopt agriculturally unavailable land in coastal areas for large-scale production of this species and its biomass utilisation for the extraction of $20 \mathrm{E}$ at commercial level.

\section{Potential applications of $S$. portulacastrum}

\subsection{Medicinal uses}

Medicinally and economically, Sesuvium containing secondary metabolites have shown a great potential as a substitute for some synthetic raw materials in the food, perfumery, cosmetic and pharmaceutical industries (LisBalchin and Deans 1997). This plant is used in traditional

Fig. 8 A. rhizogenes mediated induction of hairy roots from stem explants of $S$. portulacastrum. From left to right: after 28 days of rhizogenesis, 3-month-old hairy root culture and fully grown hairy roots (Lokhande et al. unpublished results)

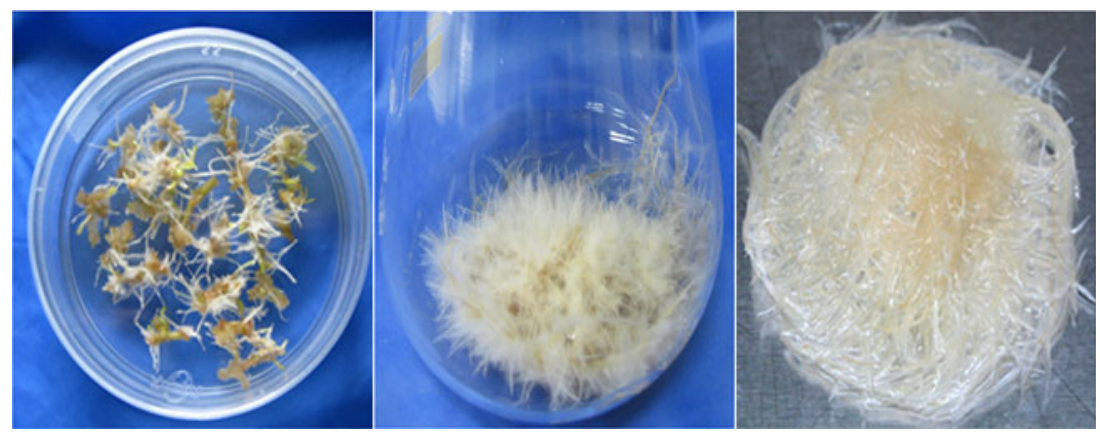


medicine as a remedy for fever, kidney disorders and scurvy (Rojas et al. 1992) by the indigenous people in Africa, Latin America and in Asian countries such as India, China, Pakistan and Japan. The plant is used on the Senegal coast as a haemostatic and a decoction of it is considered to be the best known antidote for stings of venomous fish. Leaves have acidulous flavour of sorrel as well as antiscorbutic (Anonymous 2009; Lokhande et al. 2009a). The plant is known to contain a polysaccharide, which showed positive activity against HIV (Padmakumar and Ayyakkannu 1997).

The essential oil extracted from the leaves of Sesuvium revealed notable antibacterial activity against both grampositive and gram-negative bacteria and displayed significant antifungal and antioxidant activity (Magawa et al. 2006). The essential oil showing these activities was attributed to the presence of relatively higher amount of monoterpene which was actually composed of more or less content of hydrocarbon compounds such as $O$-cymene, 2$\beta$-pinene, $\alpha$-pinene, 1, 8-cineole, limonene, $\alpha$-terpinene, $\alpha$ terpinolene and camphene. These chemical components exert their toxic effects against these microorganisms through the disruption of bacteria or fungal membrane integrity (Magawa et al. 2006). The fatty acid methyl esters (FAME extract) from Sesuvium leaves have been shown to contain higher saturated fatty acids than the unsaturated fatty acids, and the extract showed antimicrobial activity against Aspergillus fumigatus and Aspergillus niger (Chandrasekaran et al. 2011). Methanolic extracts of the plant contributed to its cholinesterase inhibitory activity which was comparable to the standard drug Donepezil used for treatment of Alzheimer's disease (Suganthy et al. 2009). Furthermore, the plant contains a rich source of alkaloids, amino acids, polysaccharides, minerals, saponins, steroids and triterpenes which have been used for antiviral activity and curing of hepatitis and other diseases (Joshi and Bhosale 1981; Premnathan et al. 1995; Padmakumar and Ayyakkannu 1997; Bandaranayake 2002).

\subsection{Source of nutritious food and fodder}

S. portulacastrum is occasionally cultivated as a vegetable for cooking purpose in India and South East Asia (Hammer 2001). It has a great potential food value and also utilised as a wild vegetable crop in the southern India because of its salty taste and fleshy nature (Kathiresan et al. 1997; Ramani et al. 2006; Lokhande et al. 2009a). A rough estimate of nutritional values revealed the content of protein $10.2 \%$, fat $0.24 \%$, total ash $33 \%$, crude fibre $9.9 \%$, carbohydrate $45.5 \%$ and calorific value $223 \mathrm{~K}$ calories. Considering its nutritional composition, the plant can be used to complement as a vegetable in the coastal region. In addition, the plants by growing in the arid and semiarid regions can provide the alternative source of fodder to domestic animals.

\subsection{Source of organic fertiliser and preservative}

A significant increase in growth and biomass production was recorded for oilseed crop Arachis hypogaea (groundnut) when it was cultivated in soil containing compost of halophytic plants (S. portulacastrum, Suaeda maritima and Ipomoea pes-caprae) along with farmyard manure and phosphatesolublising bacteria (phosphobacteria). This compost of halophytic plants was found to significantly improve the soil microflora such as bacteria, fungi and actinomycetes and soil enzyme activities such as dehydrogenase, alkaline phosphatase and urease (Balakrishnan et al. 2007). Ravindran et al. (2007) proposed the use of organic compost of these luxuriantly growing halophytes as an alternative source to chemical fertilisers for increasing the soil fertility and crop production which further add up to the value of halophytes. After 120 days of cultivation with Sesuvium, soil EC was reduced from 4.9 to $2.5 \mathrm{dS} \mathrm{m}^{-1}$, while in the plant sample, the EC was increased from 4.3 to $15.3 \mathrm{dS} \mathrm{m}^{-1}$. Sodium absorption ratio (SAR) also was reduced from 15.55 to 5.09 (67\% reduction). Furthermore, the Vigna mungo as an intercrop in the paddy field in the presence of $S$. portulacastrum along with the other mangrove compost of S. maritima, Excoecaria agallocha, Clerodendron inerme and I. pes-caprae revealed significant improvement in the growth parameters (shoot and root length, total number of leaves, fresh weight of plants, total number of root nodules, fresh weight of root nodules and total number of branches) as compared to soil devoid of compost (Balakrishnan et al. 2010). Considering the growing problems of decreasing fertility of agricultural lands in the arid and semiarid regions due to excess application of various types of toxic chemical fertilisers and their irregular availability in the market, the organic compost made up of these fast-growing halophytic plants and as an easily available nature's gift could become a potential source of fertiliser in future for the development of sustainable agriculture.

Kanth et al. (2009a, b) suggested that Sesuvium can be used as a replacement for salt in the curing process of goatskins and suggested that the quality of goatskins preserved in paste prepared of dried plant powder of Sesuvium was at par with that of skin preserved in salt. Being the type of 'salt accumulator', S. portulacastrum has opened the new branch for the use of halophytic species as a cheap source of preservative and an alternative to salt for the preservation of fishes, meat, etc. under controlled conditions.

\section{Pioneer role in environment protection}

S. portulacastrum has been reported as pioneer species for environmental protection such as sand dune fixation, saline soil stabilisation and desalination, desert greenification, landscaping as well as an ornamental (Menzel and Leith 1999). The species typically traps sand in between the 
succulent prostrate stem having crawling leaves and initiate the formation of small, widely spaced, embryonic dunes that are parallel to the shoreline (Lonard and Judd 1997).

Environmentally, the plant's potential has been checked for its survival under different abiotic stress conditions that includes salinity, drought and heavy metal accumulation which makes Sesuvium a useful species as a heavy metal pollution indicator (Lacerda 1982) and for predicting soil salinity (Tóth et al. 1997). Sesuvium being a coastal plant also acts as an inland plant and a mangrove associate and has shown to have nursing effects on mangroves. The presence of this plant in clear-cut forest in Belize has helped to accelerate mangrove recruitment in this area (McKee et al. 2007). Rabhi et al. $(2009,2010 b)$ has provided evidence for the ability of this halophyte to desalinise an experimentally salinised agricultural soil (grown for 189 days) and confirmed the growth potentials of test culture Hordeum vulgare (barley) on the desalinised soil. There was a marked absorption of $\mathrm{Na}^{+}$ ions by $S$. portulacastrum roots and their accumulation in the above-ground biomass up to $872 \mathrm{mg} \mathrm{plant}^{-1}$ and $4.36 \mathrm{~g} \mathrm{pot}^{-1}$ (about $1 \mathrm{tha}^{-1}$ ). Thus the characteristic feature of Sesuvium to accumulate high amount of salt in its tissues may be exploited for reducing salt levels in the potential agriculture soil and in the arid and semiarid regions by repetitive cultivation and harvesting of this plant in these areas (Ravindran et al. 2007). Sesuvium's remarkable ability to yield high biomass as well as transport and accumulate cadmium, lead and arsenic in its tissues in presence or absence of salt can be useful in the application of this plant for phytoextraction of these toxic heavy metals from contaminated soils (Ghnaya et al. 2005, 2007a,b; Nouairi et al. 2006; Zaier et al. 2010a, b; Lokhande et al. 2011b). In a recent study, Patil et al. (2012) reported decolorisation of a toxic textile dye Green HE4B (GHE4B) using in vitro grown plantlets of Sesuvium. The plantlets exhibited significant $(70 \%)$ decolorisation of GHE4B (50 $\mathrm{mg} \mathrm{l}^{-1}$ that sustain $200 \mathrm{mM} \mathrm{NaCl}$ within 5 days of incubation. The UV-visible spectrophotometer, HPLC and Fourier transform-infrared spectroscopy analyses of the samples before and after decolorisation of the dye confirmed the efficient phytotransformation of GHE4B in the presence of $200 \mathrm{mM} \mathrm{NaCl}$. This study has pointed out for the first time the potential of Sesuvium for the degradation of textile dyes and its efficacy on saline soils contaminated with toxic compounds. Considering the applications of Sesuvium in environment protection, strategies should be in place for the conservation and large-scale propagation of this pioneer species for environmental conservation.

\section{Summary and conclusions}

Almost all our modern crops are derived from glycophytes, plants which apparently lack the genetic basis for salt tolerance, and have received the most research attention. Although considerable research has been published on the mechanism of salt tolerance in the glycophytes, yet fewer than a dozen salt-tolerant cultivars have been released, offering only slight improvement over the parent lines. In fact, it has been debated whether any cultivars bred for salt tolerance have been commercially successful. In this context, study of halophytes can be instructive from (1) the mechanism by which halophytes survive and maintain productivity on saline water can be used to define a minimal set of adaptations required in tolerant germplasm. This knowledge can help to focus the efforts of plant breeders and molecular biologists working with conventional crop plants (Zhu et al. 1997; Glenn and Brown 1999), (2) halophytes grown in an agronomic setting can be used to evaluate the overall feasibility of high-salinity agriculture, which depends on more than finding a source of tolerant germplasm (Glenn 1987) and (3) halophytes may become a direct source of new crops.

Present review highlights the potential ability of Sesuvium through the development of various strategies to cope with various abiotic stresses, to contribute to success as a pioneer species for environment protection. In spite of the information available on the physiological and biochemical basis of tolerance to various abiotic stresses, an intensive research needs to be focused towards understanding the molecular basis of stress tolerance which could provide additional resource for the improvement of abiotic stress tolerance of crop plants. Consequently, the studies will require inputs through extensive genome sequence information using modern molecular techniques. The conservation of the species through established tissue culture protocols could be also useful to generate plant population to cover the barren lands for greenification and can augment its application in saline land for desalination purpose in the arid and semi-arid regions of the world. The biotechnological studies (such as establishment of hairy roots and cell cultures) undertaken in this plant will act as a 'biofactory' for the production of commercially important secondary metabolites which will fulfill the demands of pharmaceutical industries for required products. Further, manipulations in the biosynthetic pathway and enhancement of secondary metabolite synthesis using various elicitors and precursors could enhance the productivity of the compounds in a short span of time. Furthermore, as this plant has considerable nutritional status, it can be used as a source of food to overcome the problem of hunger of poor coastal people and by growing the plant in the arid and semi-arid regions can provide the alternative source of fodder to domestic animals. Thus $S$. portulacastrum will also help to understand salt tolerance and adaptation pathways in plants and help sustain agriculture in highly saline and heavy metal polluted soil. 


\section{References}

Adrian-Romero MS, Wilson J, Blunden G, Yang MH, Carabot-Cuervo A, Bashir AK (1998) Betaines in coastal plants. Biochem System Ecol 26:535-543. doi:10.1016/S0305-1978(98)00013-1

Agoramoorthy G, Fu-An C, Venkatesalu V, Daih-Hu AK, Po-Chuen S (2008) Evaluation of antioxidant polyphenols from selected mangrove plants of India. Asian J Chem 20(2):1311-1322

Anonymous (2009) http://www.aluka.org/action/showMetadata.

Ashraf M, Harris PJC (2004) Potential biochemical indicators of salinity tolerance in plants. Plant Sci 166:3-16. doi:10.1016/ j.plantsci.2003.10.024

Aspe H, Gussarsson M, Adalsteinson S, Lense'n P (1994) Control of potassium influx in roots of birch (Betula pendula) seedlings exposed to cadmium. J Expt Bot 45:1823-1827. doi:10.1093/ $\mathrm{jxb} / 45.12 .1823$

Attipali RR, Kolluru VC, Munusamy V (2004) Drought induced responses of photosynthesis and antioxidant metabolism in higher plants. J Plant Physiol 161:1189-1202. doi:10.1016/j.jplph.2004.01.013

Balakrishnan V, Venkatesan K, Ravindran KC (2007) The influence of halophytic compost, farmyard manure and phosphobacteria on soil microflora and enzyme activities. Plant Soil Environ 53:186-192

Balakrishnan V, Venkatesan K, Sanjiviraja K, Indrajit A, Ravindran KC (2010) Application of an organic halophytic manure on yield characteristics of Arachis hypogaea Linn. Internat J Eng Sci Technol 2:134-143. doi:59104-106459-1-PB

Bandara BMR, Jayasinghe L, Karunaratne V, Wannigama GP, Bokel M, Kraus W, Sotheeswaran S (1989) Ecdysterone from stem of Diploclisia glaucescens. Phytochem 28:1073-1075. doi:10.1016/ 0031-9422(89)80185-2

Bandaranayake WM (2002) Bioactivities, bioactive compounds and chemical constituents of mangrove plants. Wet Ecol Manag 10:421-452. doi:10.1023/A:1021397624349

Bathori M (2002) Phytoecdysteroids effects on mammals, isolation and analysis. Mini-Rev Med Chem 2:285-293. doi:10.2174/ 1389557023406269

Bhosale LJ, Shinde LS (1983a) Nitrate reductase activity in mangroves. In: All India symposium on marine plants, their biology, chemistry and utilization, Dona Paula, Goa, October 30-November 1,1983

Bhosale LJ, Shinde LS (1983b) Photosynthetic products and enzymes in a mangrove Aefgiceras corniculatum and a halophyte Sesuvium portulacastrum. Photosynthetica (Prague) 7(1):59-63

Binzel M, Ratajczak R (2002) Function of membrane transport systems under salinity: tonoplast. In: Lauchli A, Luttge U (eds), Salinity: environment plants molecules. Kluwer Academic, New York pp 423-449

Blumwald E (2000) Sodium transport and salt tolerance in plants. Curr Opin Cell Biol 12:431-434. doi:10.1016/S0955-0674(00)00112-5

Blumwald E, Grover A, Good AG (2004) Breeding for abiotic stress resistance: challenges and opportunities. In: "New directions for a diverse planet". Proceedings of the 4th International Crop Science Congress, Brisbane, Australia

Bohnert HJ, Jensen RG (1996) Strategies for engineering water stress tolerance in plants. Trends Biotechnol 14:89-97. doi:10.1016/ 0167-7799(96)80929-2

Chandrasekaran M, Senthilkumar A, Venkatesalu V (2011) Antibacterial and antifungal efficacy of fatty acid methyl esters from the leaves of Sesuvium portulacastrum L. Eur Rev Med Pharmacol Sci 15:775-80

Chen K-M, Gong GH-J, Chen CG-C, Wang WS-M, Zhang ZC-L (2004) Gradual drought under field conditions influences the glutathione metabolism, redox balance and energy supply in spring wheat. Journal of Plant Growth Regulation 23:20-28. doi:10.1007/s00344-003-0053-4
Chou WS, Lu HS (1980) Growth regulation and silk production in Bombyx mori L., from phytogenous ecdysteroids. In: Hoffman JA (ed) Progress in ecdysone research. Elsevier, Amsterdam, pp 281-297

Cushman JC (2001) Osmoregulation in plants: implications for agriculture. Amer Zool 41:758-769. doi:10.1093/icb/41.4.758

Cushman JC (2003) Functional genomics of plant abiotic stress tolerance. In: Prade RA, Bohnert HJ (eds) Genomics of Plants and Fungi. Marcel Dekker, Inc, New York, pp 315-357

Daniells IG, Holland JF, Young RR, Alston CL, Bernardi AL (2001) Relationship between yield of grain sorghum (Sorghum bicolor) and soil salinity under field conditions. Aust J Plant Exp Agri 41:211-217

Daoud S, Harrouni MC, Bengueddour R (2001) Biomass production and ion composition of some halophytes irrigated with different seawater dilutions. In: First International conference on saltwater intrusion and coastal aquifers - monitoring, modeling and management. Essaouira, Morocco, April 23-25

Delauney AJ, Verma DPS (1993) Proline biosynthesis and osmoregulation in plants. Plant J 4:215-223. doi:10.1046/j.1365313X.1993.04020215.x

Deuschle K, Funck D, Hellmann H, Daeschner K, Binder S, Frommer WB (2001) A nuclear gene encoding mitochondrial $\Delta^{1}$-pyrroline5 -carboxylate dehydrogenase and its potential role in protection from proline toxicity. Plant J 27:345-356. doi:10.1046/j.1365313X.2001.01101.x

Dinan L (2001) Phytoecdysteroids: biological aspects. Photochem 57:325-339. doi:10.1016/S0031-9422(01)00078-4

Dinan L, Lafont R (2006) Effects and applications of arthropod steroid hormones (ecdysteroids) in mammals. J Endocrinol 191:1-8. doi:10.1677/joe.1.06900

Errabii T, Gandanou CB, Essalmani H, Abrini J, Idamor M, Senhaji NS (2007) Effect of $\mathrm{NaCl}$ and mannitol induced stress on sugarcane (Saccharum sp.) callus cultures. Acta Physiol Plant 29:95-102. doi:10.1007/s11738-006-0006-1

Fan W, Zhang Z, Zhang Y (2009) Cloning and molecular characterization of fructose-1,6-bisphosphate aldolase gene regulated by high-salinity and drought in Sesuvium portulacastrum. Plant Cell Rep 28(6):975-984. doi:10.1007/s00299-009-0702-6

FAO (2008) FAO Land and Plant Nutrition Management Service. http://www.fao.org/ag/agl/agll/spush

Flowers TJ, Colmer TD (2008) Salinity tolerance in halophytes. New Phytol 179:945-963. doi:10.1111/j.1469-8137.2008.02531.x

Flowers TJ, Troke PF, Yeo AR (1977) The mechanism of salt tolerance in halophytes. Ann Rev Plant Physiol 28:89-121. doi:10.1146/ annurev.pp.28.060177.000513

Ghnaya T, Nouairi I, Slama I, Messedi D, Grignon C, Abdelly C, Ghorbel MH (2005) Cadmium effects on growth and mineral nutrition of two halophytes: Sesuvium portulacastrum and $\mathrm{Me}$ sembryanthemum crystallinum. J Plant Physiol 162(10):11331140. doi:10.1016/j.jplph.2004.11.011

Ghnaya T, Slama I, Messedi D, Grignon C, Ghorbel MH, Abdelly C (2007a) Effect of $\mathrm{Cd}^{2+}$ on $\mathrm{K}^{+}, \mathrm{Ca}^{+}$and $\mathrm{N}$ uptake in two halophytes Sesuvium portulacastrum and Mesembrynathemum crystallinum: consequences on growth. Chemosphere 67:72-79. doi:10.1016/j.chemosphere.2006.09.064

Ghnaya T, Slama I, Messedi D, Grignon C, Ghorbel MH, Abdelly C (2007b) Cd-induced growth reduction in the halophyte Sesuvium portulacastrum is significantly improved by $\mathrm{NaCl}$. J Plant Res 120:309-316, 10.1007/s10265-006-0042-3

Glenn EP (1987) Relationship between cation accumulation and water content of salt tolerant grasses and a sedge. Plant Cell Environ 10:205-212. doi:10.1111/1365-3040.ep11602236

Glenn EP, Brown JJ (1999) Salt tolerance and crop potential of halophytes. Crit Rev Plant Sci 18(2):227-255. doi:10.1080/ 07352689991309207 
Hammer K (2001) Aizoaceae. In: Hanelt P (ed), Mansfeld's encyclopedia on agricultural and horticultural crops, Institute of Plant Genetics and Crop Plant Research. Springer, Berlin, 1986, Vol 1, pp 223-227

Harada E, Yamaguchi Y, Koizumi N, Hiroshi S (2002) Cadmium stress induces production of thiol compounds and transcripts for enzymes involved in sulfur assimilation pathways in Arabidopsis. J Plant Physiol 159(4):445-448. doi:10.1078/0176-1617-00733

Hasegawa PM, Bressan RA, Zhu J-K, Bohnert HJ (2000) Plant cellular and molecular responses to high salinity. Ann Rev Plant Physiol Plant Mol Biol 51:463-499. doi:10.1146/annurev.arplant.51.1.463

Heldt HW (2005) Phenylpropanoids comprise a multitude of plant secondary metabolites and cell wall components, In: Plant Biochemistry (3rd eds). Elsevier Academic, New York, pp 448

Hong Z, Lakkineni K, Zhang Z, Verma DPS (2000) Removal of feedback inhibition of $\Delta^{1}$-pyrroline-5-carboxylate synthetase results in increased proline accumulation and protection of plants from osmotic stress. Plant Physiol 122:1129-1136. doi:10.1104/ pp.122.4.1129

Huber W (1974) Ubet den Einfluss von $\mathrm{NaCl}$ —oder Abscisins/iurehehandiung auf den Protein-Metabolismus und einige weitere Enzyme des Aminos iurestoffwechsels in Keimlingen yon Pennisetum typhoides. Planta 121:225-235

Huchzermeyer B, Hausmann, Paquet-Durant F, Koyro H-W (2004) Biochemical and physiological mechanisms leading to salt tolerance. Trop Ecol 45(1):141-150

Jena S, Sahoo P, Das AB (2003) New reports of chromosome number and genome size in eight mangroves from coastal Orissa. Caryologia 56(3):353-358

Jennings DH (1968) Microelectrode experiments with potato cells: a re-interpretation of the experimental findings. J Expt Bot 19:13. doi:10.1093/jxb/19.1.13

Joshi GV, Bhosale LJ (1981) Estuarine ecosystem of India. In: Sen DN, Tajpurohit KS (eds) Contributions to the ecology of halophytes. Dr. W. Junk Publications, The Hague, pp 21-33

Kanth SV, Kannan PR, Selvi AT, Saravanan P, Rao RJ, Nair BU, Rengaswamy R (2009a) Phytoremediation of soil using Sesuvium portulacastrum - part I: removal of $\mathrm{Na}^{+}$and $\mathrm{Cl}^{-}$from tannery wastewater treated soil. J Amer Leath Chem Asso 104:17-24

Kanth SV, Keerthi PB, Selvi AT, Sarvanan P, Rao RJ, Nair BU (2009b) Studies on the use of Sesuvium portulacastrum - part II: preservation of skins. J Amer Leath Chem Asso 104:25-32

Kathiresan K, Ravishankar GA, Venkataraman LV (1997) In vitro multiplication of a coastal plant Sesuvium portulacastrum L. by axillary buds. In: Ravishankar GA, Venkataraman LV (eds) Biotechnological applications of plant tissue and cell culture. IBH, India, pp 185-192

Klein R (2004) Phytoecdysteroids. J Amer Herbalists Guide (fall/ winter issue), pp 18-28

Koyro H-W, Salma D, Harrouni C, Huchzermeyer B (2006) Strategies of a potential cash crop halophyte (Beta vulgaris ssp. maritima) to avoid salt injury. Trop Ecol 47(2):191-200

Krupa Z, Bazynski T (1977) Participation of sulfoquinovosyl diacylglycerol in reconstitution of photosystem I activity of hapteneextracted chloroplasts. Bull Acad Political Sci Series B 25:409-414

Lacerda LD (1982) Heavy metal pollution in soil and plants of the Iraja River Estuarine area in the Guanabara Bay Brazil. Rev Brasil de Biol 42:89-94

Liao Y, Guizhu C (2007) Physiological adaptability of three mangrove species to salt stress. Acta Ecol Sin 27(6):2208-14. doi:10.1016/ S1872-2032(07)60052-3

Lis-Balchin M, Deans SG (1997) Bioactivity of selected plant essential oils against Listeria monocytogenes. J Appl Bacteriol 82:759762. doi:10.1046/j.1365-2672.1997.00153.x

Lokhande VH, Suprasanna P (2012) Prospects of halophytes in understanding and managing abiotic stress tolerance. In: Parvaiz A,
Prasad MNV (eds) Environmental adaptations to changing climate: metabolism, productivity and sustainability. Springer, New York, pp 29-56. doi:10.1007/978-1-4614-0815-4_2

Lokhande VH, Nikam TD, Patade VY, Suprasanna P (2009a) Morphological and molecular diversity analysis among the Indian clones of Sesuvium portulacastrum L. Genet Res Crop Evol 56:705-717. doi:10.1007/s10722-008-9396-9

Lokhande VH, Nikam TD, Suprasanna P (2009b) Sesuvium portulacastrum (L.) L., a promising halophyte: cultivation, utilization and distribution in India. Genet Res Crop Evol 56:741-747. doi:10.1007/s10722-009-9435-1

Lokhande VH, Nikam TD, Ghane SG, Suprasanna P (2010a) In vitro culture, plant regeneration and clonal behaviour of Sesuvium portulacastrum (L.) L.: a prospective halophyte studies on the response of growth regulators for in vitro culture and clonal behavior of six clones of a halophyte, Sesuvium portulacastrum L. Physiol Mol Biol Plants 16(2):187-193. doi:10.1007/s12298010-0020-z

Lokhande VH, Nikam TD, Suprasanna P (2010b) Biochemical, physiological and growth changes in response to salinity in callus cultures of Sesuvium portulacastrum L. Plant Cell Tiss Org Cult 102:17-25. doi:10.1007/s11240-010-9699-3

Lokhande VH, Nikam TD, Suprasanna P (2010c) Differential osmotic adjustment to iso-osmotic salt and PEG stress in vitro in the halophyte Sesuvium portulacastrum L. J Crop Sci Biotechnol 13 (4):251-256. doi:10.1007/s12892-010-0008-9

Lokhande VH, Nikam TD, Patade VY, Ahire ML, Suprasanna P (2011a) Effects of optimal and supra-optimal salinity stress on antioxidative defense, osmolytes and in vitro growth responses in Sesuvium portulacastrum L. Plant Cell Tiss Org Cult 104:41-49

Lokhande VH, Srivastava S, Patade VY, Dwivedi S, Tripathi RD, Nikam TD, Suprasanna P (2011b) Investigation of arsenic accumulation and tolerance in Sesuvium portulacastrum (L.) L. Chemosphere 82 (4):529-534. doi:10.1016/j.chemosphere.2010.10.059

Lokhande VH, Srivastava AK, Srivastava S, Nikam TD, Suprasanna P (2011c) Regulated alterations in redox and energetic status are the key mediators of salinity tolerance in the halophyte Sesuvium portulacastrum (L.) L. Plant Grow Regul 65(2):287-298. doi:10.1007/s10725-011-9600-3

Lonard RI, Judd FW (1997) The biological flora of coastal dunes and wetlands. Sesuvium portulacastrum (L.) L. J Coast Res 13(1):96104

Luettge U, Popp M, Medina E, Cram WJ, Diaz M, Griffths H, Lee HSJ, Schaefer C, Smith JAC, Stimmel KH (1989) Ecophysiology of xerophytic and halophytic vegetation of a coastal alluvial plain in northern Venezuela. V. The Batis maritime-Sesuvium portulacastrum vegetation unit. New Phytol 111(2):283-291

Luttge U, Smith JAC (1984) Structural, biophysical, and biochemical aspects of the role of leaves in plant adaptation to salinity and water stress. In: Staples RC, Toenniessen GH (eds) Salinity tolerance in plants: strategies for crop improvement. Wiley, New York, pp 125-150

Magawa ML, Gundidza M, Gweru N, Humphrey G (2006) Chemical composition and biological activities of essential oil from the leaves of Sesuvium portulacastrum. J Ethnopharmacol 103:8589. doi:10.1016/j.jep.2005.07.024

Martinez ML, Valverde T, Moreno-Casasola P (1992) Germination response to temperature, salinity, light and depth of sowing of ten tropical dune species. Oecologia 92:343-353. doi:10.1007/ BF00317460

Martinez JP, Kinet JM, Bajji M, Lutts S (2005) NaCl alleviates polyethylene glycol-induced water stress in the halophyte species Atriplex halimus L. J Expt Bot 56:2421-2431. doi:10.1093/jxb/ eri235

McKee KL, Cahoon DR, Feller IC (2007) Caribbean mangroves adjust to rising sea level through biotic controls on change in soil 
elevation. Global Ecol Biogeo 16(5):545-556. doi:10.1111/ j.1466-8238.2007.00317.x

Menzel U, Leith H (1999) Annex 4: halophyte database Vers 2. In: Leith H, Moshenko M, Lohmann M, Koyro HW, Hamdy A (eds) Halophyte uses in different climates 1 . Ecological and physiological studies. Progress in biometeorology. Backhuys, Leiden, pp 159-258

Messedi D, Labidi N, Grignon C, Abdelly C (2004) Limits imposed by salt to the growth of the halophyte Sesuvium portulacastrum. J Plant Nutr Soil Sci 167:720-725. doi:10.1002/jpln.200420410

Minoda A, Sonoike K, Okada K, Sato N, Tsuzuki M (2003) Decrease in the efficiency of the electron donation to tyrosine $\mathrm{Z}$ of photosystem II in an SQDG-deficient mutant of Chlamydomonas. FEBS Lett 553:109-112. doi:10.1016/S0014-5793(03)00981-5

Mirzaev Yu R, Syrov V (1992) Effect of phytoecdysteroids on the sexual activity of male rats. Doklady Akademii Nauk Respubliki Uzbekistana 3:47-49

Moseki B (2007) Evidence for the presence of two components of the root transmembrane potential of a halophyte Sesuvium portulacastrum (L.) L., grown under saline conditions. Scient Res Ess 2(1):013-015

Moseki B, Buru JC (2010) Ionic and water relations of Sesuvium portulacastrum (L). Scient Res Ess 5:35-40

Munns R, Tester M (2008) Mechanism of salinity tolerance. Ann Rev Plant Biol 59:651-581. doi:10.1146/annurev.arplant.59.032607.092911

Murashige T, Skoog F (1962) A revised medium for rapid growth and bioassays with tobacco tissue cultures. Physiol Plant 15:473-497. doi:10.1111/j.1399-3054.1962.tb08052.x

Nabikhan A, Kathiresan K, Anburaj R, Nabeel MA (2010) Synthesis of antimicrobial silver nanoparticles by callus and leaf extracts from saltmarsh plant, Sesuvium portulacastrum L. Coll Surf B: Biointerfaces 79:488-493. doi:10.1016/j.colsurfb.2010.05.018

Nair KS, Yun-gen M, Kumar SN (2005) Differential response of silkworm, Bombyx mori L. to phytoecdysteroid depending on the time of administration. J Appl Sci Environ Manag 9(3):8186. doi:17357-163215-1-PB

Najmutdinova DK, Saatov Z (1999) Lung local defense in experimental diabetes mellitus and the effect of 11,20-dihydroxyecdysone in combination with manilil. Arch Insect Biochem Physiol 41:144-147. doi:10.1002/(SICI)1520-6327(1999) 41:3<144:: AID-ARCH5>3.0.CO;2-0

Ninagi O, Maruyama M (1996) Utilization of 20-hydroxyecdysone extracted from a plant in sericulture. Japan Agri Res Quart $30: 123-128$

Nouairi I, Ghnaya T, Youssef NB, Zarrouk M, Ghorbel MH (2006) Changes in content and fatty acid profiles of total lipids of two halophytes: Sesuvium portulacastrum and Mesembryanthemum crystallinum under cadmium stress. J Plant Physiol 163:11981202. doi:10.1016/j.jplph.2005.08.020

Padmakumar K, Ayyakkannu K (1997) Seasonal variation of antibacterial and antifungal activities of the extracts of marine algae from Southern coast of India. Bot Mar 40:507-515. doi:10.1515/ botm.1997.40.1-6.50

Pagter M, Bragato C, Malagoli M, Brix H (2009) Osmotic and ionic effects of $\mathrm{NaCl}$ and $\mathrm{Na}_{2} \mathrm{SO}_{4}$ salinity on Phragmites australis. Aquat Bot 90:43-51. doi:10.1016/j.aquabot.2008.05.005

Patil AV, Lokhande VH, Suprasanna P, Bapat VA, Jadhav JP (2012) Sesuvium portulacastrum (L.) L.: a potential halophyte for the degradation of toxic textile dye, Green HE4B. Planta 235 (5):1051-1063. doi:10.1007/s00425-011-1556-Z

Pe'rez-Tornero O, Tallo'n CI, Porras I, Navarro JM (2009) Physiological and growth changes in micropropagated Citrus macrophylla explants due to salinity. J Plant Physiol 166(17):1923-1933. doi:10.1016/j.jplph.2009.06.009

Premnathan M, Kathiresan K, Chandra K (1995) Antiviral evaluation of some marine plants against Semliki Forest Virus. Internat J Pharmacog 33:1-3. doi:3109/13880209509088153
Rabhi M, Hafsi C, Lakhdar A, Barhoumi Z, Hamrouni MH, Abdelly C, Smauoi A (2009) Evaluation of the capacity of three halophytes to desalinize their rhizosphere as grown on saline soils under non leaching conditions. Afr J Ecol 47:463-468. doi:10.1111/j.13652028.2008.00989.x

Rabhi M, Giuntini D, Castagna A, Remorini D, Baldan B, Smaoui A, Abdelly C, Ranieri A (2010a) Sesuvium portulacastrum maintains adequate gas exchange, pigment composition, and thylakoid proteins under moderate and high salinity. J Plant Physiol 167 (16):1336-1341. doi:10.1016/j.jplph.2010.05.009

Rabhi M, Ferchichi S, Jouini J, Hamrouni MH, Koyro HW, Ranieri A, Abdelly C, Smaoui A (2010b) Phytodesalination of a salt-affected soil with the halophyte Sesuvium portulacastrum L. to arrange in advance the requirements for the successful growth of a glycophytic crop. Biores Technol 101:6822-6828. doi:10.1016/ j.biortech.2010.03.097

Ramani B, Papenbrock J, Zorn H (2004a) Quantification and fatty acid profiles of sulfolipids in two halophytes and a glycophyte grown under different salt concentrations. Z Natu 59c:835-842

Ramani B, Papenbrock J, Schmidt A (2004b) Connecting sulfur metabolism and salt tolerance mechanisms in the halophytes Aster tripolium and Sesuvium portulacastrum. Trop Ecol 45:173-182

Ramani B (2004c) Investigation of salt tolerance mechanisms in the halophytes Aster tripolium L. and Sesuvium portulacastrum L. through physiological, biochemical and molecular methods, A Ph. D. thesis, Institut fur Botanik, Austria.

Ramani B, Reeck T, Debez A, Stelzerd R, Huchzermeyera B, Schmidt A, Papenbrock J (2006) Aster tripolium L. and Sesuvium portulacastrum L.: two halophytes, two strategies to survive in saline habitats. Plant Physiol Biochem 44:395-408. doi:10.1016/ j.plaphy.2006.06.007

Raven JA (1985) Regulation of $\mathrm{pH}$ and generation of osmolarity in vascular land plants: costs and benefits in relation to efficiency of use of water, energy and nitrogen. New Phytol 101:25-77. doi: j.1469-8137.1985.tb02816.x

Ravindran KC, Venkatesan K, Balakrishnan V, Cehllappan KP, Balasubramanian $\mathrm{T}$ (2007) Restoration of saline land by halophytes for Indian soils. Soil Biol Biochem 39:26612664. doi:10.1016/j.soilbio.2007.02.005

Rhodes D, Hanson AD (1993) Quaternary ammonium and tertiary sulfonium compounds in higher plants. Annu Rev Plant Physiol Plant Mol Biol 44:357-384. doi:10.1146/annurev.pp.44.060193.002041

Rojas A, Hernandez L, Rogeho PM, Mata R (1992) Screening for antimicrobial activity of crude drug extracts and pure natural products from Mexican medicinal plants. J Ethnopharmacol 35:127-149. doi:10.1016/0378-8741(92)90025-M

Sen DN, Mohammad S, Kaser PK (2001) Biology and physiology of saline plants. In: Pessarakli M (ed) Handbook of plant and crop physiology. Marcel Dekker, New York, pp 563-581

Short DC, Colmer TD (1999) Salt tolerance in the halophyte Halosarcia pergranulata subsp. pergranulata. Annu Bot 83:207-213. doi:10.1006/anbo.1998.0812

Simon P, Krolman J (1989) Ecdysone: from chemistry to mode of action. In: Koolman JA (ed) George Thieme, New York, pp 254-259

Sinlaparaya D, Duanghaklang P, Panichajakul S (2007) Enhancement of 20hydroxyecdysone production in cell suspension cultures of Vitex glabrata $\mathrm{R}$. Br. By precursors feeding. Afr J Biotechnol 6(14):1639-1642

Slama I, Messedi D, Ghnaya T, Savoure A, Abdelly C (2006) Effects of water-deficit on growth and proline metabolism in Sesuvium portulacastrum. Environ Exp Bot 56:231-238. doi:10.1016/ j.envexpbot.2005.02.007

Slama I, Ghnaya T, Hessini K, Messedi D, Savoure A, Abdelly C (2007a) Comparative study of the effects of mannitol and PEG osmotic stress on growth and solute accumulation in Sesuvium portulacastrum. Environ Expt Bot 61:10-17. doi:10.1016/ j.envexpbot.2007.02.004 
Slama I, Ghnaya T, Messedi D, Hessini K, Labidi N, Savoure A, Abdelly C (2007b) Effect of sodium chloride on the response of the halophyte species Sesuvium portulacastrum grown in mannitol-induced water stress. J Plant Res 120:291-299. doi:10.1007/s10265-006-0056-x

Slama I, Ghnaya T, Savoure A, Abdelly C (2008) Combined effects of long-term salinity and soil drying on growth, water relations, nutrient status and proline accumulation of Sesuvium portulacastrum. C R Biol 331:442-451. doi:10.1016/j.crvi.2008.03.006

Song J, Chen M, Feng G, Jia Y, Wang B, Zhang F (2008) Effect of salinity on growth, ion accumulation and the role of ions in osmotic adjustment of two populations of Suaeda salsa. Plant Soil 102:103-112. doi:10.1007/s11104-008-9712-3

Strogonov BP (1973) Structure and function of plant cells in saline habitats. Wiley, New York, p 245

Subbarao GV, Levine LH, Wheeler RM, Stutte GW (2001a) Glycine betaine accumulation: its role in stress resistance in crop plants. In: Pessarakli M (ed) Handbook of plant and crop physiology. Marcel Dekker, New York, pp 881-907

Subbarao GV, Wheeler RM, Berry WL, Stutte GW (2001b) Sodium: a functional nutrient in plants. In: Pessarakli M (ed) Handbook of plant and crop physiology. Marcel Dekker, New York, pp 363-384

Suganthy N, Pandian SK, Devi KP (2009) Cholinesterase inhibitory effects of Rhizophora lamarckii, Avicennia officinalis, Sesuvium portulacastrum and Suaeda monica: mangroves inhabiting an Indian coastal area (Vellar Estuary). J Enz Inhibit Med Chem 24 (3):702-707. doi:10.1080/14756360802334719

Szabados L, Savoure A (2009) Proline: a multifunctional amino acid. Trends Plant Sci 15:89-97. doi:10.1016/j.tplants.2009.11.009

Tester M, Davenport R (2003) $\mathrm{Na}^{+}$tolerance and $\mathrm{Na}^{+}$transport in higher plants. Ann Bot 91:503-527. doi:10.1093/aob/mcg058

Thulasidas SK, Kulkarni MJ, Goyal N, Murali MS, Mathur JN, Page AG, Chintalwar GJ, Banerji A (1999). Studies on the uptake of U, $\mathrm{Eu}, \mathrm{Cs}$ and $\mathrm{Sr}$ by the plant Sesuvium portulacastrum for bioremediation using Analytical Spectroscopy. NUCAR 99 (Nuclear and Radiochemistry Symposium), Mumbai, January 19-22

Toroser D, Huber SC (1997) Protein phosphorylation as a mechanism for osmotic-stress activation of sucrose-phosphate-synthase in spinach leaves. Plant Physiol 114:947-955. doi:10.1104/pp.114.3.947

Tóth T, Kertesz M, Guerrat LC, Labrada JL, Machado BP, Fonseca PC, Martinez MN (1997) Plant composition of a pasture as a predictor of soil salinity. Rev Biol Trop 45:1385-1393

Treichel S (1986) The influence of $\mathrm{NaCl}$ on delta-1-pyrroline-5-carboxylate reductase in proline accumulating cell suspension cultures of Mesembryanthemum nodiflorum and other halophytes. Physiol Plant 67:173-181. doi:10.1111/j.1399-3054.1986.tb02440.x

Uchiyama M, Yoshida T (1974) Effect of ecdysterone on carbohydrate and lipid metabolism. In: Burdette WJ (ed) Invertebrate endocrinology and hormonal heterophylly. Springer, Berlin, pp 401-416

Venkatesalu V, Chellapan KP (1993) Photosynthetic characteristics of Sesuvium portulacastrum L. under salt stress. Photosynthetica 28:313-316

Venkatesalu V, Chellappan KP (1993) Photochemical characteristics of Sesuvium portulacastrum L. under sodium chloride stress. Photosynthetica 29:139-141

Venkatesalu V, Kumar RR, Chellappan KP (1994a) Growth and mineral distribution of Sesuvium portulacastrum L., a salt marsh halophyte, under sodium chloride stress. Commun Soil Sci Plant Anal 25:2797-2805. doi:10.1080/00103629409369226

Venkatesalu V, Kumar RR, Chellappan KP (1994b) Sodium chloride stress on organic constituents of Sesuvium portulacastrum L., a salt marsh halophyte. J Plant Nutr 17:1635-1645. doi:10.1080/ 01904169409364836
Vijayan K, Chakraborti SP, Ghosh PD (2003) In vitro screening of mulberry (Morus spp.) for salinity tolerance. Plant Cell Rep 22:350-357. doi:10.1007/s00299-003-0695-5

Wang LW, Showalter AM (2004) Cloning and salt-induced, ABAindependent expression of choline mono-oxygenase in Atriplex prostrate. Physiol Plant 120:405-412. doi:10.1111/j.00319317,2004. 00247.x

Wang D, Wang H, Han B, Wang B, Guo A, Zheng D, Liu C, Chang L, Peng M, Wang X (2012) Sodium instead of potassium and chloride is an important macronutrient to improve leaf succulence and shoot development for halophyte Sesuvium portulacastrum. Plant Physiol Biochem 51:53-62. doi:10.1016/j.plaphy.2011.10.009

White PJ, Broadley MR (2003) Calcium in plants. Annals of botany 92:487-511. doi:10.1093/aob/meg164

Wong LZ, Li HY, Chang YY, Zhu GQ, Shong SX, Li XH, Ye JS (1979) Identification and physiological tests of phytoecdysones from Chinese flora with the silkworm, Bombyx mori L. Acta Entomol Sin 22:396-403

Yang J, Yen HE (2002) Early salt stress effects on the changes in chemical composition in leaves of ice plant and Arabidopsis. A Fourier transform infrared spectroscopy study. Plant Physiol 130 (2):1032-1042. doi:10.1104/pp.004325

Yeo AR, Flowers TJ (1986) Salinity resistance in rice (Oryza sativa L.) and a pyramiding approach to breeding varieties for saline soils. Austr J Plant Physiol 13:161-173. doi:10.1071/PP9860161

Yokoi S, Bressan RA, Hasegawa PM (2002) Genetic engineering of crop plants for abiotic stress. In: Iwanaga M (ed) Salt stress tolerance of plants, The Japan International Centre for Agricultural Sciences (JIRCAS) Working Report No. 23, Tsukuba: Japan International Centre for Agricultural Sciences Publishing, Japan, pp 25-33

Yoshida T, Otaka T, Uchiyama M, Ogawa S (1971) Effect of ecdysterone on hyperglycemia in experimental animals. Biochem Pharmacol 20:3263-3268. doi:10.1016/0006-2952(71)90431-X

Zaier H, Ghnaya T, Lakhdar A, Baioui R, Ghabriche R, Mnasri M, Sghair S, Lutts S, Abdelly C (2010a) Comparative study of Pbphytoextraction potential in Sesuvium portulacastrum and Brassica juncea: tolerance and accumulation. J Haz Mat 183(13):609-615. doi:10.1016/j.jhazmat.2010.07.068

Zaier H, Mudarra A, Kutscher D, Fernandez de la Campa MR, Abdelly C, Sanz-Medel A (2010b) Induced lead binding phytochelatins in Brassica juncea and Sesuvium portulacastrum investigated by orthogonal chromatography inductively coupled plasma-mass spectrometry and matrix assisted laser desorption ionization-time of flight-mass spectrometry. Anal Chim Acta 671(1-2):48-54. doi:10.1016/j.aca.2010.04.054

Zeng HC, Deng LH, Zhang CF (2006) Cloning of salt tolerance-related cDNAs from the mangrove plant Sesuvium portulacastrum L. J Integ Plant Biol 48:952-957. doi:10.1111/j.1744-7909.2006.00287.x

Zhang JS, Xie C, Li ZY, Chen SY (1999) Expression of the plasma membrane $\mathrm{H}^{+}$-ATPase gene in response to salt stress in a rice salttolerant mutant and its original variety. Theoret Appl Genet 99:1006-1011

Zhang F, Yang YL, He WL, Zhao X, Zhang LX (2004) Effects of salinity on growth and compatible solutes of callus induced from Populus euphratica. In Vitro Cell Dev Biol- Plant 40:491-494. doi:10.1079/IVP2004546

Zhu JK (2001) Plant salt tolerance. Trends Plant Sci 6:66-71. doi:10.1016/S1360-1385(00)01838-0

Zhu JK, Hasegawa PM, Bressan RA (1997) Molecular aspects of osmotic stress in plants. Clin Crit Rev Plant Sci 16:253-277. doi:10.1080/07352689709701950 